\title{
Etkili Okul Öncesi Öğretmenlerinin Kișisel Özellikleri: Kısa Hikaye Çalıșması*
}

\section{Özlem YURT***, Sadiye KELEŞ***}

Öz: Nitelikli bir okul öncesi eğitimin göstergeleri arasında yer alan eğitim programı ve eğitim ortamı gibi temel boyutları en üst düzeyde kullanarak, eğitim sürecini etkili uygulamalarla gerçekleştirecek kişiler okul öncesi öğretmenleridir. Diğer tüm öğretmenlik branşlarında olduğu gibi, okul öncesi öğretmenliğinde de öğretmenlerin taşıması gereken özellikler tartışmaya açık bir konudur. Ancak görüş birliğine varılan konu, öğretmenlerin mesleği seçmelerinde etkili olan geçmiş yaşantılarının, çocuk gelişimi bilgilerinin, inanışlarının ve öz-saygılarının yüksek nitelikteki öğrenme ortamları için önemli olduğu düşüncesidir. Bu doğrultuda bu çalışmanın temel amacı; okul öncesi öğretmenlerinin, etkili okul öncesi öğretmenlerinin kişisel özelliklerine sahip olma durumlarının kısa hikayeler yoluyla incelenmesidir. İkinci amac1 ise, okul öncesi öğretmenlerin etkili okul öncesi öğretmeni özelliklerini sergileme düzeyleri arasındaki ilişkinin belirlenmesidir. Araştırmada katılımcıların belirlenmesinde amaçlı örnekleme yöntemi kullanılmış ve 54 öğretmen araştırmaya gönüllü olarak dahil olmuştur. Verilerin toplaması amacıyla, araştırmacılar tarafından kurgulanan çeşitli kısa hikayeleri içeren yarı-yapılandırılmış görüşme formu kullanılmıştır. İlgili kısa hikayeler, Colker'ın (2008) öne sürdüğü 12 farklı öğretmen özelliğini (heves/coşku, sonuna kadar direnme, risk almaya isteklilik, pragmatizm, sabır, esneklik, farklılıklara saygı duyma, yaratıcılık, otantiklik, öğrenmeyi sevme, yüksek enerji ve mizah duygusu) yansıtacak şekilde kurgulanmıştır. Verilerin analizinde bütünsel rubrikten ve korelasyon analizinden yararlanılmıştır. Araştırma sonucunda; katılımcıların çoğunluğunun hevesli/coşkulu olma ve otantik olma özelliklerini sergilemelerinin yeterli düzeyde olduğu; yaratıcı olma özelliğini sergileme konusunda iyileştirilme ihtiyacında oldukları; pragmatist olma ve öğrenmeyi sevme özelliğini sergilemede ise yetersiz düzeyde oldukları görülmüştür. Bununla birlikte, hevesli/coşkulu olma ile pragmatist olma puanları ve yaratıcı olma ile yüksek enerjiye sahip olma puanları arasında negatif yönlü anlamlı bir ilişki; sonuna kadar direnme ile farklılıklara saygı gösterme puanları arasında ise pozitif yönlü anlamlı bir ilişki tespit edilmiştir.

\footnotetext{
${ }^{*}$ Bu çalışma 27th European Early Childhood Education Research Association (EECERA) Annual Conference (29th August - 1 st September 2017, Italy) poster bildiri olarak sunulmuştur.

**Dr. Öğr. Ü., Trabzon Üniversitesi, Fatih Eğitim Fakültesi, Temel Eğitim Bölümü Email: ozlemyurt37@gmail.com

***Dr. Öğr. Ü. Zonguldak Bülent Ecevit Üniversitesi, Ereğli Eğitim Fakültesi Temel Eğitim Bölümü. 
Anahtar Kelimeler: Okul öncesi eğitimi, Etkili öğretmen özelliği, Kısa hikaye Personal Characteristics of Effective Preschool Teachers: A Vignette Study

Abstract: Preschool teachers are those who are expected to implement the educational process with effective practices by making utmost use of the basic dimensions such as the educational programme and educational setting, considered to be amongst the determiners of a high-quality preschool education. As in all other teaching specialties, the characteristics that preschool teachers need to possess are also open to debate. Consensus is reached, however, on the view that teachers' previous experiences influential on their professional choice, their knowledge of child development, their beliefs, and their self-esteem are essential for highquality learning settings. The main purpose of this study is to examine the preschool teachers' personal characteristics of effective pre-school teachers through vignettes. The second aim is to determine the relationship between effective pre-school teacher characteristics. Purposive sampling method was used for the selection of the participants and 54 teachers volunteered to take part in the study. For data collection, a semi-structured interview form composed of various short stories and based on the scenario approach was developed by the researchers. The vignettes were created in a way that reflected the 12 different characteristics of a teacher (passion, perseverance, willingness to take risks, pragmatism, patience, flexibility, respect for diversity, creativity, authenticity, love of learning, high energy, and sense of humour) proposed by Colker (2008). The holistic rubric and correlation analysis were used for the analysis of the data. The study concludes that preschool teachers demonstrate a sufficient degree of flexibility but prove inadequate in terms of love of learning and pragmatism. The findings of this study are expected to shed light on preschool teacher education policies. As a result of the research; that the majority of the participants were enthusiastic and authentic; they need to be improved in terms of being creative; pragmatists and love of learning are inadequate. However, there is a significant negative relationship between being enthusiastic with being a pragmatist and being creative with having a high energy score; a significant positive correlation was found between the perseverance and the appreciation of diversity.

Keywords: Preschool education, Effective teacher characteristics, Vignette

\section{Giriş}

Nitelikli bir okul öncesi eğitimin göstergeleri arasında yer alan eğitim programı ve eğitim ortamı gibi temel boyutları en üst düzeyde kullanarak, eğitim sürecini etkili uygulamalarla gerçekleştirecek olan kişiler okul öncesi öğretmenleridir. Diğer tüm öğretmenlik 
branşlarında olduğu gibi, okul öncesi öğretmenliğinde de etkili öğretmenlerin taşıması gereken özellikler tartışmaya açık bir konudur. Etkili öğretmenin özelliklerinin tanımlanmasında, öğretmen etkililiği kavramı kritik bir öneme sahiptir. Öğretmen etkililiği ve etkili öğretmen özelliklerinin mercek altına alındığı çalışmalar incelendiğinde, araştırmaların yaygın olarak etkili öğretmenlerin mesleki özelliklerine (Ay ve Yurdabakan, 2015; Külekçi, 2018; Özkan ve Arslantaş, 2013; Şen ve Erişen, 2002) odaklandıkları, bazı araştırmaların ise hem kişisel hem mesleki özelliklere (Bozkuş ve Taştan, 2016; Breault, 2013; Dinçer, Göksu, Takkaç ve Yazıcı, 2013; Şahin, 2013) vurgu yaptığı görülmektedir. Etkili öğretmenlerin mesleki açıdan sahip oldukları özelliklere ilişkin bilimsel araştırma sonuçları özetlendiğinde, etkili öğretmenler için sözel beceriler, öğretmen yetiştirme programlarındaki eğitsel görevler (öğretmenlik meslek bilgisi), sertifikalandırma, alan bilgisi, öğretmenlik deneyimi, risk altındaki ve üstün yetenekli çocuklarla çalışma gibi özelliklerin, ön koşul niteliği taşıdığı saptanmıştır (Stronge, 2018).

Etkili öğretmenlerin kişisel özellikleri incelendiğinde ise, Cartwright (1999) iyi bir okul öncesi öğretmeni olmanın çocukları sevmekten, bu alanda eğitim almak ve deneyim sahibi olmaktan çok daha öte olduğunu savunmaktadır. Etkili öğretmenlerin kişisel açıdan taşıdıkları özelliklerin mesleğe ilişkin heves/coşku (Colker, 2008; Keller, Goetz, Becker, Morger, ve Hensley, 2014; Patrick, Hisley ve Kempler, 2000; Wood, 1998), yeniliğe değişime ve öğrenmeye açık olma (Colker, 2008; Morrison, 2004), olumlu iletişim sergileme (Cartwright, 1999; Stronge, Ward ve Grant, 2011), adil olma (Cartwright, 1999; Stronge, Ward ve Grant, 2011), farklılıklara saygı duyma (Cartwright, 1999; Colker, 2008), saygınlık (Stronge, Ward ve Grant, 2011), mizah anlayışı/kullanımı (Cartwright, 1999; Colker, 2008), azim/sonuna kadar direnme (Colker, 2008), pragmatizm (Colker, 2008), sabırlı olma (Colker, 2008), esneklik (Colker, 2008), yaratıcılık (Colker, 2008), otantik olma/ öz-farkındalığa sahip olma (Cartwright, 1999; Colker, 2008), risk almaya istekli olma (Colker, 2008) gibi özellikler olduğu saptanmiştır.

Görüldüğü gibi, etkili öğretmenlerin sahip olduğu mesleki özellikler gibi, kişisel özellikleri hakkında da uzun bir liste oluşturmak mümkündür. Ancak özellik kavramının kişisel algılarla şekillendiği düşünüldüğünde, etkili öğretmenlerin ortak özelliklerinin sınıflandırmasının yapılmasında, hizmet içindeki öğretmenlerin görüşlerinin daha somut öneriler içerebileceği bir gerçektir. Colker'1n (2008) gerçekleştirdiği araştırma bu bağlamda oldukça değerlidir. Colker (2008) 43 okul öncesi eğitim uygulayıcıyla gerçekleştirdiği araştırmasında, etkili öğretmenlerin kişisel özelliklerine ilişkin temel bir liste elde etmiştir. Araştırma sonucuna göre etkili okul öncesi öğretmenlerinin sahip olduğu 12 kişisel özellik; 
heves/coşku, sonuna kadar direnme, risk almaya isteklilik, pragmatizm, sabır, esneklik, farklılara saygı, yaratıcılık, otantiklik, öğrenmeyi sevme, yüksek enerji ve mizah anlayışıdır. Aşağıda bu özelliklere ilişkin kısa açıklamalara yer verilmiştir.

Çeşitli araştırmalar (Erdiller ve McMullen; 2003; Şahin, 2013; Şahin-Sak, TantekinErden ve Pollard-Durodola, 2018) sınıfın fiziksel özelliklerinin (Sınıf mevcudu, mobilyalar, bölünmüş öğrenme alanları gibi) öğretmenlerin uygulamaları üzerinde etkili olduğunu ortaya koymuştur. Bu nedenle, diğer öğretmenlik branşlarında olduğu gibi, okul öncesi eğitiminin yüksek nitelikte uygulanmasının önündeki engellerden bazılarının fiziksel ve finansal zorluklar olduğunu söylemek mümkündür. Bu ve diğer başka zorluklar, öğretmenlerde tükenmişlik kaynağı olabilmekte ya da öğretmenlerin iş/meslek doyumlarını olumsuz yönde etkileyebilmektedir. Ancak öğretmenler, bu fiziksel ya da finansal güçlükleri ortadan kaldırma çabalarının ya da ilgili durumu iyileştirmeye yönelik girişimlerinin etkili olduğunu gördüklerinde ve bir fark yaratabildiklerini hissettiklerinde, yapmakta oldukları uygulamaları gerçekleştirmeye devam edebilirler ve motivasyonları artabilir (Colker, 2008). Öğretmenlerin içsel motivasyonlarını sürdürmelerini ve güdülenememe düzeylerini azaltmalarını sağlayacak temel öğretmen özelliği ise öğretmen coşkusudur. Öğretmen coşkusunu takip eden diğer bir özellik azimli olma veya sonuna kadar direnmedir. Sınırlı sayıda araştırma, öğretmen-okul idarecileri, okul idarecileri-üst kurumlar arasında görüş farklıları (Jorde-Bloom, 1988) ve iletişimde bazı sınırlılıklar (Büte ve Balc1, 2010) olduğuna ilişkin bulgular sunmaktadır. Sonuna kadar direnme özelliği, bu tür durumlarda, öğretmenlerin, çocukların ihtiyaçlarının veya eğitim sorunlarının çözümüne dair inandıkları yollar için mücadele etmeye istekli olmalarını ifade etmektedir. Öğretmenler, çocukların ve ailelerinin hayatlarını iyileştirmek için uzun vadeli savunucular olmaya istekli olmalıdır. Etkili öğretmenler, gerektiğinde bürokratik engellerin kısa sürede ortadan kalkmasını sağlayabilecek ya da bunların üstesinden gelebilecek yolları dirençli bir şekilde arayacak öğretmenlerdir (Colker, 2008). Öğretmenlerin çocuk çıkarlarının savunucusu olması, aynı zamanda risk almalarını da gerektirmektedir. Bu noktada etkili öğretmenlerin bir diğer ortak özelliği risk almaya istekli olmalarıdır. Çocukların çıkarlarının savunulması, aileleri ve çocukları güçlendirme, özel gereksinimlere sahip çocuklar için kaynak bulma, toplumun okul öncesi eğitimi ile ilgili olumsuz tutumlarını değiştirme ve okul öncesi eğitim alanında uzmanlaşmayı teşvik etme gibi yollarla gerçekleştirilebilmektedir (Akt. Liebovich ve Adler, 2009) Savunuculuk girişimleri, en basit seviyede bile, öğretmenlerin çocuklarla ve aileleri ile yaşayabileceği daha karmaşı sorunlara çözüm bulma konusunda beceri ve deneyim kazanmalarına yardımcı olmaktadır. Çocuk çıkarları ile ilgili bir durumu 
derinden hisseden bir öğretmen, durumla başa çıkmak için yeni fikirleri öne sürmekte veya yöntemleri geliştirmekte çeşitli adımlar atmaktadır. Bu durum, öğretmenin diğer çalışma arkadaşlarıyla veya sorumlu diğer personelle çatışma yaşamasını ve yeni çözümlere katılmayan diğer kişiler tarafından reddedilme riskini doğurabilmektedir (Lindamood, 1995). Pragmastist öğretmenler bu tür riskleri almaya istekli öğretmenlerdir. Sonuna kadar direnme ve risk almaya istekli olmanın, öğretmenleri hedeflerine ulaştırabilmesi ancak öğretmenin pragmatist olması ile mümkün olmaktadır. Pragmatist öğretmenler genellikle ödün vermeye hazır kişilerdir, hangi mücadeleyi kazanılabileceklerini ve çocuklarını desteklemek için kaynaklarını ne zaman kullanacaklarını bilirler. Etkili öğretmenler, küçük kazançlar elde etseler de hedeflerine doğru ilerlediklerini bilmektedirler. Pragmatizm doğrultusunda uygulamaya konabilecek olan özelliklerden birisi ise sabırlı olmadır. Hem eğitim sistemi içerisinde hem de çocuklarla ve ailelerle çalışırken, sabırlı olmak gerekmektedir. Her çocuğun gelişim ve öğrenme hızı birbirinden farklıdır, bu nedenle çocuklar tekrar tekrar hatırlatıcılara ihtiyaç duyabilirler. Bunun yanı sıra ailelerin ya da çocukların bazı davranışları, en etkili öğretmeni bile zaman zaman zorlayabilmektedir. Etkili öğretim sabır gerektirmektedir (Colker, 2008). Etkili uygulamalar sabrın yanı sıra eğitim sürecinin, planlı tasarımını gerektirmektedir. Ancak bazen önceden planlanan tasarılar, çeşitli nedenlerle sekteye uğrayabilmektedir. Bu durum birçok okul öncesi öğretmeni tarafından yaşanan ortak durumlardan birisidir. Örneğin bir öğretmen planladığı açık hava etkinliğini, hava yağışı nedeniyle iptal etmek durumunda kalabilir ya da planladığı bir etkinlikte çoğaltılması gereken bir materyali fotokopi makinasının bozuk olması nedeniyle çoğaltamayabilir. Bu tür durumlarda, hızlı bir şekilde alternatif çözümler üreten, tüm aksaklıkların üstesinden gelebilen, bu anlamda esnek olan öğretmenler etkili öğretmenlerdir (Bean-Mellinger, 2018; Colker, 2008).

Etkili öğretmenlerin bir diğer özelliği ise farklılıklara saygı duymalarıdır. Öğretmenlerin farklılıklara saygı duyması durumu, farklılıkların, öğretmenler tarafından yalnızca kabul edilmesini ya da hoşgörü temelinde davranışlar ile karşılık bulmasını değil, aynı zamanda takdir edilmesini ifade etmektedir. Çocuklar çevrelerinden kabul ve saygı gördükleri durumlarda olumlu benlik kavramı geliştirebilirler (Colker, 2008; Roegholt, Wardekker ve Van Oers, 1998). Bu nedenle öğretmenlerin sınıflarında çoğulcu bir yaklaşım içerisinde olmaları önemlidir. Bir diğer etkili okul öncesi öğretmeni özelliği ise yaratıcı olmaktır. Farklı şekillerde düşünen ve öğrenen farklı öğrenme stilleri olan çocukların gelişimlerini desteklemek ve en önemlisi, öğrenmeyi eğlenceli hale getirmek yaratıcılık gerektirir. Yaratıcılık, etkili bir okul öncesi öğretmeni için temel sembollerden birisidir (Colker, 2008). Etkili bir okul öncesi 
öğretmeni olabilmenin önemli bileşenlerin biri de öğretmenin kendini bilmesi ve bireysel özelliklerinin okul öncesi eğitim sınıflarındaki eğitim-öğretim sürecine ve karar verme süreçlerine nasıl etki ettiğinin farkında olmasıdır (Baum ve King, 2006). Otantik olmak bir öğretmenin eğitim ortamında neden bulunduğunun ve neyi temsil ettiğinin farkında olması anlamını taşımaktadır (Colker, 2008). Öğretmenlerin eğitim ortamı içerisindeki rollerinin başında çocukların keşif sürecini başlatmak ve merakları için kışkırtıcı bir aktör olmak geldiği düşünüldüğünde otantik olmanın ön koşulunun çocuk merkezli uygulamaların benimsenmesinden geçtiği yadsınamaz bir gerçektir. Öğretmenlerin ve öğretmen adaylarının çocuk merkezli uygulamalar konusundaki inançlarının ve uygulamalarının incelendiği araştırmalar bu iki yapı arasında kısmen paralellik olduğunu (Hegde ve Cassidy, 2009; Sak, Tantekin-Erden ve Morrison, 2016-2018; Şahin-Sak, Tantekin-Erden ve Pollard-Durodola, 2018) ve bu yöndeki inanışlarının sınıf içi uygulamalarının bir yordayıcısı olmadığını (Rentzou ve Sakellariou, 2011) ortaya koymuştur. Etkili öğretmen, kendi yetersizliklerinin farkına varmaya çalışır, gelişimi isteğe bağlı bir süreç olarak değil olağan ve zorunlu bir süreç olarak algılar, "yaşam boyu öğrenme ve gelişme” felsefesini benimser (Can, 2004).

Okul öncesi eğitimi alanında yapılan çalışmalar arttıkça, bu alandaki eğitim ile ilgili bilgi ve beceriler de değişmektedir. Bu durum, öğrenmeyi sevmenin ve öğrenme için çaba göstermenin mesleki gelişimde merkezi bir rol oynadığı ve etkili öğretmenlerin özelliklerinden biri olduğu anlamına gelmektedir. Birçok öğretmen, çocuklarının gelişimlerini desteklemek için harcadıkları zamandan daha fazlasını kendilerini eğitmek ve geliştirmek için harcamaya gereksinim duymalıdır (Morrison, 2004). Bu noktada "değişime hazır olma” kavramı kritik bir kavram haline gelmektedir.

Dinamik, neşe dolu, eğlence eğilimi yüksek, yüksek enerjiye sahip öğretmenler çocukların coşkusunu arttıran öğretmenlerdir. Her ne kadar eğilimden çok öğretmenlerin mizacıyla ilgili olsa da, öğretmenlerin yüksek enerjiye sahip olmaları önemli nitelikler arasındadır (Colker, 2008). Öğretmen etkiliği ile ilişkili olan bir diğer yapı ise öğretmenin mizah kullanımı ve mizah anlayışıdır (Bryant, Comisky, Crane ve Zillmann, 1980). Araştırmacılar, mizahı kullanan öğretmenlerin çalışma arkadaşları ve eğitim verdiği kişiler tarafından daha olumlu değerlendirildiğini; diğerleri ise mizahın öğrenmeyi geliştirebileceğini ileri sürmüşlerdir. $\mathrm{Bu}$ hipotez çeşitli araştırmalarla doğrulanmıştır: Öğretmenlerin mizah kullanımının, öğrenme üzerinde (Gorham ve Christophel, 1990; Ziv, 1988) ve sahip oldukları mizah tarzlarının stresle başa çıkmada etkili olduğu (Özdemir, Sezgin, Kaya ve Recepoğlu, 2011) bilinmektedir. Bu konuda cinsiyet faktörü önemli bir belirleyici olabilmektedir: Örneğin 
mizahın etkisi erkek çocuklar ve erkek öğretmenler açısından daha belirgindir. Buna ek olarak mizah kullanımının kadın öğretmenlerin değerlendirmelerini olumsuz etkilediği ve kadın öğretmenlerin mizahının erkek öğretmenlerin mizahından büyük ölçüde farklı olduğunu destekleyen araştırma bulguları mevcuttur (Gorham ve Christophel, 1990).

Etkili öğretmen özelliklerinin incelendiği araştırmalara bakıldığında genellikle anket tekniğinin (Ay ve Yurdabakan, 2015; Külekçi, 2018; Şen ve Erişen, 2002) kullanıldığı, bazı araştırmalarda ise hem anket hem de görüşme tekniğinin bir arada kullanıldığı (Çakmak ve Gündüz, 2018; Liu, Liu, Stronge ve Xu, 2016) karma desenli araştırmalar olduğunu söylemek mümkündür. Ancak inançların, değerlerin ve normların ampirik çalışması, araştırmacılar için her zaman zor metodolojik sorular ortaya koymuştur (Finch, 1987). En iyi düzenlenmiş ankette bile, değer ve tutumları inandırıcı biçimde incelemede zorluklarla karşılaşılmaktadır (Marsh, 1982). Örneğin bir bireyin, bir anket ya da tutum ölçeğinin maddesindeki işaretlemeleri, kişinin ilgili maddedeki işaretlemelerini, bu anlamda normları, inançları ve tutumları ilişkin yanıtlarını, başka durumlara transfer edip edemeyeceğine yönelik varsayımsal genellemeleri gerektirmektedir. Bu genellemeler ciddi sınırlılıklar içerebilmektedir. Bunun yanı sıra anketler belirli kalıplarla ya da normlarla şekillenmiş olan (normatif) konu başlıklarının karmaşık doğasını ortaya koyma konusunda çeşitli kısıtlamalar barındırmaktadır. Veri toplama aracı olarak kısa hikayelerden yararlanmak ise, normatif konuları, gerçekte kuşatıldığı karmaşıklıklara yaklaşacak şekilde ya da en azından, bu karmaşıklıkları yansıtmak için, anketlerde yaygın olarak kullanılan diğer tekniklerden daha yakın bir şekilde yaklaşma firsatı sunmaktadır (Finch, 1987). Genel olarak kısa hikayeler, kişilerin yargıları ve karar vermeleri ile ilgili belirli soruları test etmek için etkili bir şekilde tasarlandığında, "gerçek hayat" davranışına oldukça genelleştirilebilirken, alternatif yöntemlerle ilgili etik, pratik ve bilimsel sınırlamaların üstesinden gelebilmektedir (Evans ve diğ., 2015). Bu nedenle kısa hikayeler, çeşitli alanlardaki (tıp, eğitim bilimleri gibi) uzmanların yargılarını ve eylemlerini analiz etmek için bir araştırma aracı olarak ve grup benzerlikleri ile yanıtlardaki farklılıkları ortaya çıkarmaya kaynaklık edecek şekilde yaygın olarak kullanılmıştır (Boulton, Hardcastle, Down, Fowles ve Simmonds, 2014; Egyed ve Short, 2006; Jeffries ve Maeder, 2005). Aşağıda kısa hikayelerin eğitim araştırmalarında kullanımına ilişkin detaylı bilgiye yer verilmiştir.

\section{Eğitim Bilimleri Araştırmalarında Kısa Hikayelerin Kullanımı}

Kısa hikayeler (vignette), katılımcıların yargılarını dayandırmaları için gerekli bilgileri içeren, varsayımsal olarak (hipotetik) oluşturulmuş kişilerin ya da durumların kısa açıklamalarını ifade etmektedir. Kısa hikayeler, genellikle sabit tutulan hayali bir arka plandan 
ve gözlem içeriklerinden oluşan metinlerdir (Huebner, 1991). Miles (1990), kısa hikayeleri, görevi başındaki bir alan uzmanının bir anlık durumu veya mini filmini ortaya koyan bir yapı olarak tanımlamaktadır.

Kısa hikayelerin kullanımı, öğretmenlerin okul içi uygulamalarına doğrudan etki edebilmektedir (Miles, 1990; Soto, 2018). Bu nedenle mesleki gelişimin desteklenmesi açısından kritik ve etkili araçlardan biri olarak görülmektedir (Angelides ve Gibbs, 2006; Jeffries ve Maeder, 2005). Jeffries ve Maeder (2009), gerçekleştirdikleri araştırma ile kısa hikayelerin kullanımını içermeyen öğretimsel etkinliklerle karşılaştırıldığında, kısa hikayelerin kullanımına dayalı öğretimsel uygulamaların bilginin transfer edilmesinde daha etkili olduğunu ve bir konu alanının öğrenimine verilen desteği daha da zenginleştirdiğini ortaya koymuştur. Soto (2018) ise 11 okul öncesi öğretmeni ile birlikte yürüttüğü karma desenli araştırmasında, kısa hikayeler temelli mesleki gelişim oturumları ve odak grup görüşmeleri öncesi ve sonranda tutulan yansıtıcı günlükler kullanmıştır. Araştırma sonucunda öğretmenlerin günlük program, farkındalık ve destekleme temalarında olumlu yönde anlamlı değişikliklerin olduğunu tespit etmiştir. Buna paralel olarak kısa hikaye tabanlı mesleki gelişim, yansıtıcı günlük kaydı ile birleştiğinde, okul öncesi dönem çocuklarının eğitimini olumlu yönde etkileyebilecek, öğretmenlerin bilinçli öğretime ilişkin farkındalıklarını arttırmak için etkili bir yöntem olduğuna ilişkin yorumlar yapılmıştır.

Kısa hikayeler eğitsel bir araç olabildiği gibi bir değerlendirme aracı olarak da kullanılabilmektedir. Örneğin Jeffries ve Maeder (2005), k1sa hikayelerin öğretmen eğitiminde eğitimsel bir değerlendirme aracı olup olmadığını sınadıkları araştırmada, öğretmenlerin kısa hikayelerden elde ettikleri puanlar ile ara sinavdan elde ettikleri puanlar arasında anlamlı bir bağlantı olduğunu göstermiş ve kısa hikayelerin öğretmenlerin pedagojik anlayışını ölçmede güvenilir bir değerlendirme aracı olabileceğine vurgu yapmışlardır. Kısa hikayelerin kullanımı, nitel araştırmalarda genellikle karmaşık, dağınık olan ve anlaşılması kolay olmayan bir yapının analiz edilmesinde sistemli ve metodolojik bir yol sunmaktadır (Angelides ve Gibbs, 2006).

Etkili okul öncesi öğretmenlerinin kişisel özelliklerinin çok parçalı bir yapıya sahip olduğu ve normatif bir nitelik taşıdığı düşünüldüğünde, bu özelliklerin ölçülmesinde kısa hikayelerden yararlanılmasının ölçmeyi kuvvetlendirebileceğini söylemek mümkündür. Bu doğrultuda bu çalışmanın temel amacı; okul öncesi öğretmenlerinin, etkili okul öncesi öğretmenlerinin kişisel özelliklerine sahip olma durumlarının kısa hikayeler yoluyla incelenmesidir. İkinci amac1 ise, okul öncesi öğretmenlerin etkili okul öncesi öğretmeni özelliklerini sergileme düzeyleri arasındaki ilişkinin belirlenmesidir. 


\section{Yöntem}

Araştırma iki aşamadan oluşmaktadır. İlk aşama katılımcıların, etkili okul öncesi öğretmenlerinin kişisel özelliklerine sahip olma durumlarının kısa hikayeler yoluyla belirlenmesi, ikinci aşama ise katılımcıların etkili okul öncesi öğretmeni özelliklerini sergileme düzeyleri arasındaki ilişkinin incelenmesidir. Araştırmanın ilk aşamasında nitel araştırma modellerinden fenomenolojik desen, ikinci aşamasında ise genel tarama modellerinden ilişkisel tarama modeli kullanılmıştır. Fenomenolojik araştırma bir fenomenin, bireylerin ya da belirli bir grubun deneyimleri açısından incelenmesidir (Christensen, Johnson ve Turner, 2015).

\section{Katılımcılar}

Çalışmanın katılımcılarının belirlenmesinde amaçlı örnekleme yöntemlerinden maksimum çeşitlilik örneklemesi kullanılmıştır. Maksimum çeşitlilik örneklemesi, örneklemin problemle ilgili olarak kendi içerisinde benzeşik farklı durumların belirlenerek oluşturulmasıdır (Büyüköztürk, Kılıç Çakmak, Akgün, Karadeniz ve Demirel, 2013). Bu çalışmada maksimum çeşitlilik örneklemesi ile katılımcıların belirlenmesinde, Burden'in (1980) görüşleri temel alınarak öğretmenlerin çalışma yılları değişkeni dikkate alınmıştır. Burden (1980) Öğretmen Gelişimi Kuramı'nda öğretmenlerin mesleki kariyerlerinde üç gelişim aşamasından geçtiklerini vurgulamaktadır. Bu aşamalar varlığını sürdürme aşaması olan ilk yıl; uyum aşaması olan ikinci, üçüncü ve dördüncü yıl; olgunluk aşaması olan beşinci yıl ve sonrasıdır. Bu doğrultuda 2016-2017 eğitim-öğretim yılının ilk döneminde Sakarya ve Trabzon illerindeki farklı çalışma yıllarında olan, Milli Eğitim Bakanlığı'na bağlı devlet okullarında çalışmakta olan, 54 okul öncesi öğretmeni araştırmaya gönüllü olarak dahil olmuştur. Katılımcıların özelliklerine bakıldığında; öğretmenlerin 45'i kadın ve 9'u erkek iken, 15 öğretmen ilk gelişim (ilk y1l), 18 öğretmen ikinci gelişim (2-4. yı1), 21 öğretmen ise üçüncü gelişim (5. y1l +) aşamasındadır. Çalışmaya katılan öğretmenler K1, K2, K3, K4,...K54 şeklinde kodlanmıştır.

\section{Veri Toplama Aracı}

Araştırmanın verileri, araştırmacılar tarafından oluşturulan çeşitli kısa hikayelerden oluşan yarı-yapılandırılmış görüşme formu ile toplanmıştır. Kısa hikayeler, çoklu çözümlerin olduğu sorunlara yönelik tartışmaları ve olası farklı çözümleri ortaya koymak amacıyla gerçek yaşam durumlarını yansıtmak için yazılmış eksik kısa hikayeler olarak tanımlanmaktadır. Bu tanımlama doğrultusunda kısa hikayeler için beş kriter belirtilmektedir; (1) Diyalog, vaka çalışması, vaka hikayesi veya senaryo değil, bir hikaye/anlatıdır, (2) 50-200 kelime arasındadır,

(3) Katılımcıların gerçek yaşamları ile ilişkilidir, (4) Doğrudan bir puanlama anahtarına (rubriğe) bağlıdır, (5) Kısa hikayeler, tamamlanmamış ya da sonlanmamış durumları içerir 
(Jeffries ve Maeder, 2005; 2006). Bu ölçütler doğrultusunda ilgili kısa hikayeler, araştırmacılar tarafından Colker’ın (2008) öne sürdüğü 12 farklı öğretmen özelliğini (heves/coşku, sonuna kadar direnme, risk almaya isteklilik, pragmatizm, sabır, esneklik, farklılıklara saygı duyma, yaratıcılık, otantiklik, öğrenmeyi sevme, yüksek enerji ve mizah duygusu) yansıtacak şekilde kurgulanmıştır. Kısa hikayelerde hikayelerin cinsiyete duyarlı olması açısından iki farklı yarıyapılandırılmış görüşme formu oluşturulmuştur. Erkek öğretmenler için hazırlanan formda kısa hikayelerin öznesinde erkek ismi (Selim Öğretmen gibi) kullanılırken, kadın öğretmenler için ise kadın ismi kullanılmıştır (Emine Öğretmen gibi). Araştırmacıların oluşturduğu kısa hikayeler, okul öncesi eğitimi alanında uzman olan üç kişi tarafından değerlendirilmiştir. Uzman görüşü formu oluşturulurken, ilgili kısa hikayelerin hangi öğretmen özelliğine karş1lık geldiği belirtilmemiş, uzmanlardan ilgili kısa hikayelerin karşıllğı olduğunu düşündüğü öğretmen özelliğini kısa hikayelere ataması istenmiştir. Uzmanlardan gelen atamalar ve öneriler doğrultusunda düzenlenen yarı-yapılandırılmış görüşme formunun kısa hikayelerin anlaşılabilirliğini test etmek amacıyla beş okul öncesi öğretmeni ile pilot çalışma gerçekleştirilmiştir. Elde edilen bilgiler doğrultusunda form gözden geçirilerek son hali verilmiştir. Formun ilk kısmında katılımcıları oluşturan öğretmenlerin genel bilgilerine (cinsiyet, kıdem vb.) yer verilmiştir. İkinci kısımda ise 12 adet kısa hikayeye yer verilmiş ve her hikayenin ardından katılımcıların cevapları için bir alan boş bırakılmıştır. Araştırmacılar çalışmaya katılmaya gönüllü olan öğretmenlerle yüz yüze görüşerek formları iletmiştir. Katılımcılar formu doldurduktan sonra geri alınmıştır. Kısa hikayelere ilişkin detaylı açıklamalar Tablo 1'de sunulmuştur.

Tablo 1. Öğretmen Özelliklerine İlişkin Kısa Hikayeler

\begin{tabular}{|c|c|}
\hline $\begin{array}{c}\text { ÖĞRETMEN } \\
\text { ÖZELLİĞİ }\end{array}$ & KISA HİKAYELER \\
\hline Heves/Coşku & $\begin{array}{l}\text { Emine Öğretmen, çocuklarla çalışmayı çok seven bir okul öncesi öğretmenidir. Son } \\
\text { yıllarda maddi açıdan birtakım sorunlar yaşamaktadır. Öğretmenlik mesleğinden aldığı } \\
\text { maaş, yaşadığı maddi problemin çözümü için yeterli değildir. Emine Öğretmen'in yerinde } \\
\text { olsaydınız ne yapardınız? }\end{array}$ \\
\hline $\begin{array}{c}\text { Sonuna Kadar } \\
\text { Direnme }\end{array}$ & $\begin{array}{l}\text { Ceren Öğretmen Urfa Siverek Sislice Köyü’ndeki bir ilkokula okul öncesi öğretmeni } \\
\text { olarak atanmıştır. İlkokulun anasınıfına gittiğinde anasınıfının bulunduğu katta çocuklar } \\
\text { tarafından kullanılabilecek bir tuvalet/lavabo olmadığını gözlemlemiştir. Bu gözlemini } \\
\text { okul müdürüne iletmiş ve anasınıf içinde bir lavaboya/tuvalete ihtiyaç duyduklarını } \\
\text { belirtmiştir. Okul müdürünün cevabı ise ödenek olmadığı için bir lavabo/tuvalet } \\
\text { yapamayacakları yönünde olmuştur. Bunun üzerine Ceren Öğretmen, İlçe Milli Eğitim } \\
\text { Müdürlüğü'ne giderek tuvalet/lavabo ihtiyacı içinde olduklarını bildirmiştir. İlçe Milli } \\
\text { Eğitim Müdürlüğü'nden aldığı cevap ise ödenek geldiği zaman tuvalet/lavabo } \\
\text { ihtiyaçlarının karşılanacağı ancak ödeneğin ne zaman geleceğinin belli olmadığı yönünde } \\
\text { olmuştur. Ceren Öğretmen'in yerinde siz olsaydınız ne yapardınız? }\end{array}$ \\
\hline & $\begin{array}{l}\text { Arzu okul öncesi öğretmenidir. Son birkaç haftada sınıfındaki bazı çocukların } \\
\text { resimlerinde silah tank ve gözyaşı içeren çizimler yaptıklarını ve dramatik oyunlarında } \\
\text { savaş temalı oyunlar (bombalar, silahlar, ölen insanlar, anne-babasını kaybeden ve ağlayan } \\
\text { çocuklar) gerçekleștirdiklerini gözlemlemiştir. Arzu Öğretmen, bu çocukların medyadan }\end{array}$ \\
\hline
\end{tabular}


Risk Almaya olumsuz etkilendiğini ve okul içinde belirli bir sınıfta/odada bir rehberlik uzmanından İsteklilik savaşın dolaylı etkilerinden kurtulmaya yönelik danışmanlık almaları gerektiğini düşünmektedir. Ancak böyle bir uygulama görev yaptığı okulda daha önce hiç gerçekleştirilmemiştir ve çalışma arkadaşları böyle bir uygulamaya şüpheyle yaklaşmaktadır. Arzu Öğretmen'in yerinde siz olsaydınız ne yapardınız?

Sevil Öğretmen okul öncesi öğretmenidir. Çocukların 1-10’a kadar ritmik sayması kazanımı doğrultusunda sınıf içinde çeşitli etkinlikler gerçekleştirmiştir. Ancak sınıfındaki çocuklardan bazılarının ritmik saymanın mantığını kavrayamadıklarını ve 1,7,5,6 şeklinde

Pragmatizm saydıklarını gözlemlemiştir. Bu nedenle saymanın mantığını kavramaya yönelik çok çeşitli etkinlikler düzenlemiştir. Sevil Öğretmen, daha sonra gerçekleştirdiği 1-10’a kadar ritmik sayma etkinliğinde başarılı olamayan çocukların 1,2,3,5,6,7,9,10 olarak saydığını gözlemlemiştir. Sevil Öğretmen'in yerinde siz olsaydınız bu çocuklarla ilgili ne düșünürdünüz?

Elif Öğretmen okul öncesi öğretmenidir. Sınıfındaki çocuklardan bazıları kalem tutma ve kağıt-göz arasındaki mesafeyi ayarlama konusunda çeşitli sorunlar yaşamaktadır. Elif Öğretmen eğitim-öğretim yılının başından itibaren masa başında gerçekleştirilen her

Sabır kalem-kağıt etkinliği sırasında bu çocuklara nasıl oturmaları ve kalemi nasıl tutmaları gerektiği konusunda çeşitli hatırlatmalar yapmıştır. Aralık ayına gelmiş olmalarına rağmen çocuklardan bazıları çizgi çalışmaları sırasında masadaki kağıda oldukça fazla yaklaşmaktadır. Elif Öğretmen'in yerinde siz olsaydınız ne yapardınız?

Demet Öğretmen okul öncesi öğretmenidir. Ekim ayında dış bahçede yaprak toplama

Esneklik etkinliği planlamıştır. Demet Öğretmen etkinliğin planlandığı gün havanın yağmurlu olmasından dolayı dış bahçe etkinliğini iptal etmek zorunda kalmıştır. Demet Öğretmen'in yerinde siz olsaydınız ne yapardınız?

Özlem okul öncesi öğretmenidir. Özlem Öğretmen'in sınıfına Kasım Ayında Azerbaycan'dan Türkiye’ye göç etmiş bir ailenin kızı olan Gülbala dahil olmuştur. Özlem Öğretmen nezaket sözcüklerinin kullanımı ile ilgili bir etkinlik sırasında, Gülbala'nın

Farklılıklara “özür dilerim” ifadesi yerine "üzr istzyirəm”, "afiyet olsun” ifadesi yerine "nuş olsun”," Saygı rica ederim” ifadesi yerine “khahiş edərəm” ifadelerini kullandığını fark etmiştir. Özlem Öğretmen, sınıfındaki diğer çocukların Gülbala'nın nezaket sözcüklerini söylerken kullandığı lehçeye şaşırdıklarını ve Gülbala'nın her nezaket sözcüğü ifadesinde gülümsediklerini gözlemlemiştir. Özlem Öğretmen'in yerinde siz olsaydınız bu durumda nasil bir tepki verirdiniz?

Seda Öğretmen okul öncesi öğretmenidir. Seda Öğretmen'in sınıfında yer alan çocukların birçoğu, vücutlarını, ellerini ve dokunma duyularını kullandıkları etkinliklerde- daha hızlı öğrenmekte ve ilerleme göstermektedir. Sınıftaki 2 çocuk ise,

Yaratıcılık işitselliğin ve müziğin kullanıldığı etkinliklerde daha kalıcı öğrenmeler gerçekleştirmektedir. Seda Öğretmen çocuklara kare kavramını kazandırmak amacıyla bir etkinlik planlamak istemektedir. Seda Öğretmen'in yerinde siz olsaydınız nasıl bir etkinlik yapardınız?

Duygu Öğretmen okul öncesi öğretmenidir. Duygu Öğretmen o gün boyama etkinliği için tüm çocuklardan boya malzemelerini alarak masalara oturmalarını istemiştir. Boya malzemelerini alarak masalara oturan çocuklara boyanacak kağıtları dağıtmıştır. Kağıtları

Otantiklik alan çocuklar bir an önce boyamaya başlamak için sabırsızlanmaktadır. Bazı çocuklar Duygu Öğretmen'in yönergesini beklemeden boyamaya başlamıştır. Bu sırada Ahmet Duygu Öğretmen'in yanına gelerek kendisine ait boya malzemelerini bulamadığını söylemiştir. Duygu Öğretmen'in yerinde siz olsaydınız Ahmet'e vereceğiniz cevap ne olurdu?

Merve Öğretmen okul öncesi öğretmenidir. Okulun başlamasından bu yana 2 ay geçmiş olmasına rağmen güne başlama etkinliği sırasında sınıfındaki çocukların birçoğunun

Öğrenmeyi Sevme koşuşturmak, bağırıp çağırmak ve tepinmek gibi istenmeyen davranışlar sergilemeye devam ettiğini fark etmiştir. Merve Öğretmen geçtiğimiz 2 ay içinde çocuklardaki istenmeyen davranışları azaltma konusunda bildiği tüm yolları denemiştir. Ancak etkili sonuçlar elde edememiştir. Merve Öğretmen'in yerinde siz olsaydınız ne yapardınız?

Hatice Öğretmen okul öncesi öğretmenidir. Hareket etkinliği kapsamında 3 gün süresince çocuklara eşli olarak gerçekleştiren bir dansın öğretimi vermiştir. Hatice Öğretmen 3. günün sonunda kendisini fiziksel olarak bitkin hissetmektedir. O gün, gün sonunda tüm Yüksek Enerji gelmemiştir. Velisi daha sonra gelen Ege, Hatice Öğretmen'e “Öğrendiğimiz dansı 
anneme gösterebilir miyim?" diye sormuştur. Ege'nin bunun için müziğe ve bir eşe ihtiyacı vardır. Hatice Öğretmen'in yerinde siz olsaydınız bu çocuğa nasıl bir tepki verirdiniz?

Sevgin Öğretmen saçları düz olan bir okul öncesi öğretmenidir. O gün saçlarına farklı bir görünüm vermek için kuaföre gitmiş ve saçlarını kıvırcık görünümlü olacak şekilde

Mizah Duygusu ş̧ekillendirmiştir. Sevgin Öğretmen’i ilk defa kıvırcık saçlı olarak gören çocuklardan biri Sevgin Öğretmen'in saçlarını işaret ederek “Öğretmenim çok komik olmuşsun, palyaçoya benzemişsin.” diyerek kahkaha atmıştır. Sevgin Öğretmen’in yerinde siz olsaydınız bu cocuğa nasıl bir tepki verirdiniz?

\section{Verilerin Analizi}

Verilerin analizinde çalışmanın ilk aşaması için bütünsel rubrikten yararlanılmıştır. Bütünsel rubrik, performansın özünü yakalamak için ve tek bir doğrunun olmadığı durumlarda kullanılmaktadır (Morrow, Mood, Disch ve Kang, 2016). Araştırmanın yapısı gereği parçalı bir yapıda olan öğretmen özelliklerini bir bütün olarak değerlendirebilmek için bütünsel rubrikten yararlanılmıştır. Bu doğrultuda araştırma, 54 okul öncesi öğretmeninin 12 farklı kısa hikayeye verdikleri cevapların derecelendirilmesi yolu ile puanlanmıştır. Puanlamalarda dörtlü derecelemeye sahip bütünsel rubrik kullanılmıştır: Yetersiz (0), iyileştirilmeye ihtiyaç (1), yeterli (2) ve örnek niteliğinde (3) şeklindedir. Öğretmenlerin kısa hikayelere verdikleri cevaplar, rubrikte listelenen kategorilere göre “0-3” arasında derecelendirilmiştir. Bütünsel rubriğe ilişkin tanımlamalar Tablo 2'de verilmiştir.

Tablo 2. Bütünsel Rubrik Anahtarı

\begin{tabular}{ll}
\hline Performans Düzeyi & Performans Tanımları \\
\hline Yetersiz (0) & İlgili özelliği sergileme eğilimi yoktur. \\
\hline $\begin{array}{l}\text { İyileştirilmeye ihtiyaç } \\
(1)\end{array}$ & $\begin{array}{l}\text { İlgili özelliği kısmen sergilemektedir. Ancak özelliğin sergilenmesi iyileştirilmeye } \\
\text { açıktır. }\end{array}$ \\
\hline Yeterli (2) & İlgili özelliği sergileme eğilimi mevcuttur. \\
\hline Örnek niteliğinde (3) & İlgili özellik üst düzeyde sergilenmektedir. \\
\hline
\end{tabular}

Çalışmanın ikinci aşamasında ise araştırmaya dahil olan katılımcıların etkili okul öncesi öğretmeni özelliklerini sergileme düzeyleri arasındaki ilişkiyi belirlemek amacıyla, katılımcılardan elde edilen ham verilerin bir önceki basamakta bütünsel rubrik aracıyla nominal yapıya dönüştürülmesi nedeniyle korelasyon analizinde Spearman Sıra Farkları Korelasyon analizi yapılmıştır.

\section{Geçerlilik ve Güvenirlik}

Çalışmada yarı-yapılandırılmış görüşme formu ile elde edilen cevaplar ayrıntılı olarak yazıya aktarılmış ve bulgular içerisinde katılımcıların cevaplarına doğrudan alıntılar yoluyla yer verilerek geçerlik sağlanmaya çalışılmıştır. Bununla birlikte çalışma için tercih edilen amaçlı örnekleme yöntemlerinden maksimum çeşitlilik örneklemesi, "araştırma sonuçlarının genellenebilirliği” (Glesne, 2012) açısından nitel araştırmaların dış geçerliğine ilişskin ipuçları 
vermesi açısından önemlidir. Araştırmaya gönüllü olarak katılan okul öncesi öğretmenlerinin, çalışma yılları açısından geniş bir çeşitlilik içinde olması, çalışmaların sonuçlarında benzer görüşlerin elde edilebileceğini göstermektedir. Bütünsel rubriğin güvenirliliği için ise puanlayıcılar arası güvenirlik tekniğinden yararlanılmıştır. Okul öncesi öğretmenlerinin cevapları araştırmacılar tarafından ayrı ayrı değerlendirilerek puanlanmıştır. İki bağımsız kodlayıcıdan elde edilen kodlamaların birbiriyle uyumunu incelemek amacıyla Cohen Kappa katsayısı (Cohen's $\kappa)$ kullanılmıştır. Yapılan hesaplama sonucunda Cohen Kappa katsayısı hevesli/coşkulu olma özelliği için $\kappa=0.93$; sonuna kadar direnme özelliği için $\kappa=0.54$; risk almaya istekli olma özelliği için $\kappa=0.52$; pragmatist olma özelliği için $\kappa=0.81$; sabırlı olma özelliği için $\kappa=0.73$; esnek olma özelliği için $\kappa=0.82$; farklılıklara sayg1 duyma özelliği için $\kappa=0.60$; yaratıcı olma özelliği için $\kappa=0.70$; otantik olma özelliği için $\kappa=0.78$; öğrenmeyi sevme özelliği için $\kappa=0.82$; yüksek enerjiye sahip olma özelliği için $\kappa=0.85$; mizah duygusuna sahip olma için $\kappa=0.97$ olarak belirlenmiştir. $\mathrm{Bu}$ oranlar Landis ve Koch' un (1977) sınıflandırmasında "orta dereceli” olarak gösterilen .41-.60 aralığında; “yüksek uyum” olarak gösterilen .61-.80 ve "neredeyse mükemmel uyum” olarak gösterilen .81-1 aralığında bulunmaktadır.

\section{Bulgular}

Etkili okul öncesi öğretmenlerinin kişisel özelliklerine sahip olma durumlarını incelemek amacıyla elde edilen bulgular hevesli/coşkulu olma, sonuna kadar direnme, risk almaya istekli olma, pragmatist olma, sabırlı olma, esnek olma, farklılıklara saygı duyma, yaratıcı olma, otantik olma, öğrenmeyi sevme, yüksek enerjiye sahip olma ve mizah duygusuna sahip olma kategorilerinde sunulmuştur. Katılımcıların bu kategorilere yönelik kısa hikayelere verdikleri cevapların genel dağılımı Grafik 1'de yer almaktadır.

Grafik 1. Katılımcıların Kısa Hikayelere Verdikleri Cevaplara İlişkin Dağılım 


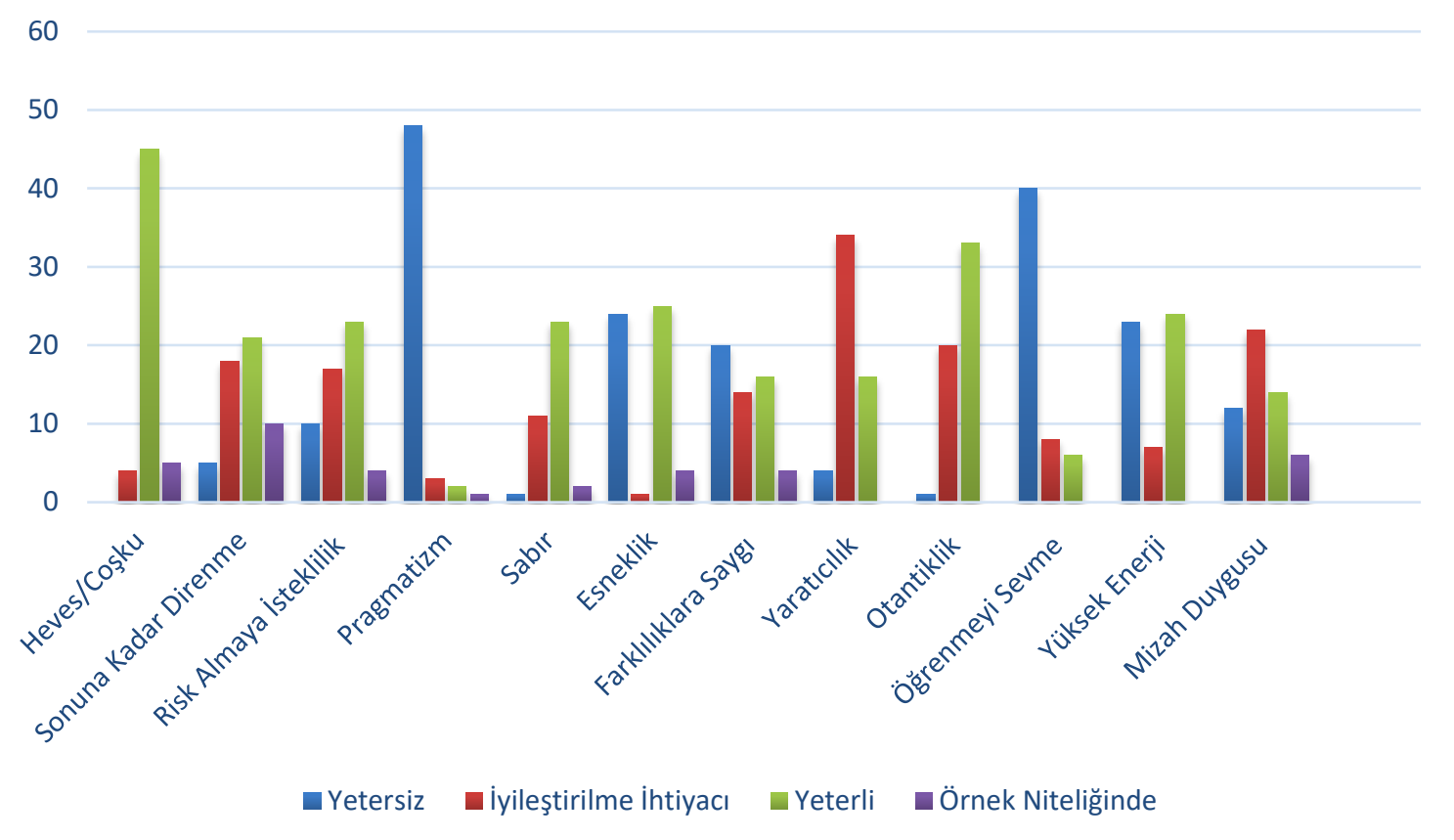

Grafik 1 incelendiğinde katılımcıların çoğunluğunun hevesli/coşkulu olma ve otantik olma özelliklerini sergilemelerinin yeterli düzeyde olduğu; yaratıcı olma ve mizah duygusuna sahip olma özelliğini sergileme konusunda iyileştirilme ihtiyacında oldukları; pragmatist olma ve öğrenmeyi sevme özelliğini sergilemede ise yetersiz düzeyde oldukları tespit edilmiştir.

Tablo 3. Katılımcıların Hevesli/Coşkulu Olma Özelliğine İlişkin Cevapları

\begin{tabular}{|c|c|c|}
\hline Rubrik & $\mathbf{N}$ & Katılımcıların Cevaplarından Örnekler \\
\hline $\begin{array}{l}\text { İyileştirilme } \\
\text { İhtiyacı }\end{array}$ & 4 & $\begin{array}{l}\text { K3: "Mesleğime devam ederdim”. } \\
\text { K7: "Harcamalarımı kısardım. Tasarruf yapmaya çalışırdım". }\end{array}$ \\
\hline Yeterli & 45 & $\begin{array}{l}\text { K4: "Sabahçıysam öğleden sonra öğlenciysem öğleden önce yapabileceğim işler arardım. } \\
\text { Mesela çocuk bakımı gibi". } \\
\text { K11: "Mesleğime uygun hafta sonları halk ĕgitim kurslar açardım ekstra gelir olması } \\
\text { için”. } \\
\text { K52: "Sevdiğim görevimi yine her zaman olduğu gibi devam ettirirdim. Maddi yönden } \\
\text { okuldan arta kalan zamanda el becerisi ile ilgili çalışmalar yapıp satabilirim. Mesai } \\
\text { dışında farklı bir işle meşgul olarak gelir elde edebilirim". }\end{array}$ \\
\hline $\begin{array}{l}\text { Örnek } \\
\text { Niteliğinde }\end{array}$ & 5 & $\begin{array}{l}\text { K9: “Uygun hareket etmem gerekir diye düşünür ilave gelir getiren işleri yapmam. } \\
\text { Öğretmenlik mesleğinin yanında ilave bir mesleğim olsa bile okul öncesi ögretmenliği } \\
\text { benim ruhum diyerek, getirisi fazla olan mesleği değil, bana haz ve mutluluk veren } \\
\text { mesleğimi yaparım. Ayağımı da yorganıma göre uzatırım. Mesleki doyum bence maddeden } \\
\text { daha önemlidir”. }\end{array}$ \\
\hline
\end{tabular}

Tablo 3 incelendiğinde, katılımcıların çoğunluğunun (N:45) hevesli/coşkulu olma özelliğini yeterli düzeyde sergiledikleri görülmektedir. Bununla birlikte bu özelliğe ilişkin az sayıda (N:5) katılımcının örnek niteliğinde açıklamalar yaptığı ve iyileştirilme ihtiyacında (N:4) olduğu tespit edilmiştir.

Tablo 4. Katılımcıların Sonuna Kadar Direnme Özelliğine İlişkin Cevapları

\begin{tabular}{lcl}
\hline Rubrik & N & \multicolumn{1}{c}{ Katılımcıların Cevaplarından Örnekler } \\
Yetersiz & 5 & $\begin{array}{l}\text { K32: “Okulun tuvaletlerini kullanırdım. Ancak kullanırken diğer okulun öğrencilerinin } \\
\text { orada olmadı̆̆ saatleri kullanmaya özen gösterirdim”. } \\
\text { K37: “Diğer katlardaki tuvaletlerden birini temin etmeye çalışırdım”. }\end{array}$ \\
\hline
\end{tabular}




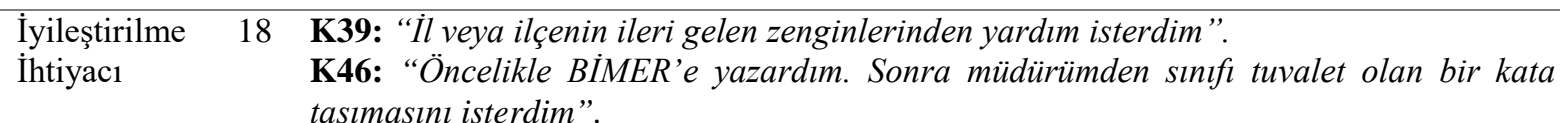
K28: "Bu zorunlu bir ihtiyaç olduğu için önce il milli eğitim müdürlüğü gibi üst Yeterli 21 yardım toplardım biraz da kendim ilave edip sınıfım için tuvalet/lavabo yaptırırdım”. K36: "Köydeki muhtar ile görüşüp köyün maddi yönden daha güçlü olan insanlarına bu sorunu iletirdim. Köy halkı ve velilerle ortak çalışmalar planlardım (kermes, köydeki kadınların elişlerini satma vb)".

Örnek

K11: "Okul müdüründen anasınıfi çocuklarının tuvalet ihtiyacı için işkur elemanlarından

Niteliğinde

10 birini okul saati bitene kadar sinıftan sorumlu olarak görevlendirmesini talep ederim. Aynı zamanda İlçe Milli Ĕ̆itim Müdürlügüne de ısrarla gereksinimimi hatırlatır. Uygun görülen durumlarda kaymakam ya da gerekli üst merci ile görüşürdüm”.

Tablo 4 incelendiğinde, katılımcıların çoğunluğunun (N:21) sonuna kadar direnme özelliğini yeterli düzeyde sergiledikleri görülmektedir. Bununla birlikte bu özelliğe ilişkin bir diğer çoğunluktaki (N:18) katılımcının iyileştirilme ihtiyacında olduğu (N:18) ve örnek niteliğinde (N:10) açıklamalar yaptıkları tespit edilmiştir. Az sayıda (N:5) katılımcının ise bu özelliği yetersiz düzeyde sergilediği görülmektedir.

Tablo 5. Katılımcıların Risk Almaya İstekli Olma Özelliğine İlişkin Cevapları

\begin{tabular}{|c|c|c|}
\hline Rubrik & $\mathbf{N}$ & Katılımcıların Cevaplarından Örnekler \\
\hline & & $\begin{array}{l}\text { K7: "Kendim halletmeye çalışırdım. Çocuklarla bireysel olarak tek tek görüşürdüm. } \\
\text { Velileri bu konuda bilgilendirirdim”. }\end{array}$ \\
\hline Yetersiz & 10 & $\begin{array}{l}\text { K45: "Çocuklarla barışın ne demek olduğu, savaşın kötü olduğunu anlatan bir etkinlik } \\
\text { planı uygulardım". }\end{array}$ \\
\hline \multirow[t]{2}{*}{$\begin{array}{l}\text { İyileştirilme } \\
\text { İhtiyacı }\end{array}$} & 17 & $\begin{array}{l}\text { K5: "Veli toplantısı yapıp çocukları medyadan uzak tutmalarını söylerdim ve durumu } \\
\text { anlatırdım. Rehber ögretmen olmadığı için araştırma yapıp sınıfta gerekli uygulamayı } \\
\text { kendim yapardım”. }\end{array}$ \\
\hline & & $\begin{array}{l}\text { K30: "Bizzat kendim, öncelikle medyanın olumsuz etkileriyle ve bu konuda yapmamız } \\
\text { gerekenlerle ilgili çocuklar, ögretmenler ve veliler için görsel bir sunum hazırlardım. } \\
\text { Sonrasında çocuklarla birkaç hafta savaşın ve bu tür kayıpların bizler üzerindeki etkisi ile } \\
\text { ilgili çeşitli drama, resim gibi rahatlatıcı; çocukların kendilerini istedikleri gibi ifade } \\
\text { edebildikleri bir süreç yaratmaya çalışırım". }\end{array}$ \\
\hline \multirow{3}{*}{ Yeterli } & \multirow{3}{*}{23} & $\begin{array}{l}\text { K11: "Bu konuyu velilerle görüşüp çocuklara bu tarz haber izletmemelerini söylerdim. } \\
\text { Rehberlik uzmanı konusunda çalışma arkadaşlardan ziyade en üst merciiyi ikna etmeye } \\
\text { çalışırdım. Rehberlik bölümünden mezun olan arkadaşlarımdan bu konuyla ilgili yardım } \\
\text { alırdım”. }\end{array}$ \\
\hline & & $\begin{array}{l}\text { K17: “Bu tarz çalışmalardan örnekler araştırır ve olumlu sonuçlar alabileceğimizi } \\
\text { anlatır. Arkadaşlarımı destek olmaya ikna etmeye çalışırım”. }\end{array}$ \\
\hline & & $\begin{array}{l}\text { K35: “Öncelikle velilerle görüşüp çocukların televizyondaki olumsuz görüntülerden uzak } \\
\text { tutmalarını isterim. Sonra meslektaşlarıma daha önce yapılan çalışmaları göstererek ikna } \\
\text { etmeye çalışırdım”. }\end{array}$ \\
\hline Örnek & & $\begin{array}{l}\text { K6: "Şüpheyle yaklaşsalar da ısrarla bunun yapılması gerektiğini anlatırdım ama bu } \\
\text { konuda idare ve diğer okul ögretmenleri hala katı tutumunu devam ettiriyorsa kendi }\end{array}$ \\
\hline Niteliğinde & 4 & $\begin{array}{l}\text { sınıfımı düşünür bunu idareden ve arkadaşlarımdan gizli olarak sınıfımda } \\
\text { gerçekleştirirdim. Sınıfıma kendi imkanlarımla ulaştığım bir rehberlik uzmanını konuk } \\
\text { olarak misafir ederdim. Gerçekten amacıma ulaşır mıyım bilmiyorum ama devamında da } \\
\text { rehberlik uzmanının önerileriyle sorunu çözmeye çalışırdım bir nebze de olsa”. }\end{array}$ \\
\hline
\end{tabular}
Tablo 5 incelendiğinde, katılımcıların çoğunluğunun (N:23) risk almaya istekli olma özelliğini yeterli düzeyde sergiledikleri görülmektedir. Bununla birlikte bir diğer çoğunluktaki (N:17) katılımcının bu özelliğe ilişkin iyileştirilme ihtiyacında olduğu ve özelliği yetersiz 
düzeyde sergilediği (N:10) tespit edilmiştir. Az sayıda (N:4) katılımcının ise örnek niteliğinde açılamalar yaptıkları görülmektedir.

Tablo 6. Katılımcıların Pragmatist Olma Özelliğine İlişkin Cevapları

\begin{tabular}{|c|c|c|}
\hline Rubrik & $\mathbf{N}$ & Katılımcıların Cevaplarından Örnekler \\
\hline Yetersiz & 48 & $\begin{array}{l}\text { K25: “Ailelerle iletişime geçerdim. Çocuklarındaki bu durumdan ve sınıf içi yaptığım } \\
\text { çalışmalardan bahsederdim. Çocuklarla daha yakından ilgilenmelerini isterdim. I̧çlerinde } \\
\text { bazı çocuklar öğrenme güçlügü yasayan özel çocuklar olabilir”. } \\
\text { K48: “İlk olarak bu çocukların yeterli olgunluk düzeyine ulaşmadı̆̆ını düşünürdüm. } \\
\text { Zamanla hala bu şekilde devam ederse bu çocukları rehberlik servisi ile görüşürürdüm”. } \\
\text { K54: “4 ve } 8 \text { rakamını çocuklara tam olarak kavratamadığımı, çocukların ritmik saymayı } \\
\text { kavramadığını düşünürüm”. }\end{array}$ \\
\hline $\begin{array}{l}\text { İyileştirilme } \\
\text { İhtiyacı }\end{array}$ & 3 & $\begin{array}{l}\text { K21: "Bir ilerleme olduğunu ancak bunun yavaş gerçekleştiğini düşünürdüm. Bu } \\
\text { çocukların hazırbulunuşluklarının düşük olmasından dolayı biraz daha zamana } \\
\text { ihtiyaçları olduğunu belirli aralıklarla aynı konuda etkinlikler yaparak bu sorunu } \\
\text { aşabileceklerine inanırdım". }\end{array}$ \\
\hline Yeterli & 2 & $\begin{array}{l}\text { K35: “Çocuklarda olumlu bir gelişme olduğunu düşünerek kullandığım yönteme devam } \\
\text { ederdim”. }\end{array}$ \\
\hline $\begin{array}{l}\text { Örnek } \\
\text { Niteliğinde }\end{array}$ & 1 & $\begin{array}{l}\text { K40: “Çocuklarda olumsuz bir durum olduğunu düşünmezdim. Yaptığım etkinliklerle } \\
\text { oldukça düzeltme sağlamışım. Daha çeşitli etkinlikler de ekleyerek eskileri düzeltmeye } \\
\text { çalışırım. Aynı etkinliklerin ev ortamında da desteklenmesini sağlarım”. }\end{array}$ \\
\hline
\end{tabular}

Tablo 6 incelendiğinde, katılımcıların çoğunluğunun (N:48) pragmatist olma özelliğini

yetersiz düzeyde sergiledikleri görülmektedir. Bununla birlikte az sayıda (N:3) katılımcının bu özellikte iyileştirilme ihtiyacında olduğu ve bu özelliği yeterli (N:2) düzeyde sergiledikleri görülmektedir.

Tablo 7. Katılımcıların Sabırlı Olma Özelliğine İlişkin Cevapları

\begin{tabular}{|c|c|c|}
\hline Rubrik & $\mathbf{N}$ & Katılımcıların Cevaplarından Örnekler \\
\hline Yetersiz & 1 & $\begin{array}{l}\text { K48: "Çocukların üzerine gitmezdim. Sürekli uyarmazdım. Kă̆ıda fazla yaklaşan } \\
\text { çocuklarda göz bozukluğumu var diye düşünürdüm. Başka şekilde bunu deneyip } \\
\text { anlamaya çalışırdım. Ailesiyle görüşürdüm. Çocuğun boyu yetmediği için, kollarl } \\
\text { uzanmadığı içinde bunu yapıyor olabilir". }\end{array}$ \\
\hline $\begin{array}{l}\text { İyileştiril } \\
\text { İhtiyacı }\end{array}$ & 11 & $\begin{array}{l}\text { K9: "Eğilenlere özel özgün fazla eğilmenin zararlarını anlatan bir şarkı söylerdim. Bir } \\
\text { de onun etkisinden daha etkili doğru duruşa şarkı söylerdim. İki şarkıyı okuma yazma } \\
\text { etkinliğinde duruma göre kullanırdım”. } \\
\text { K17: " Bu çocukların aileleri ile görüşüp evde de bu tarz çalışmalar yapmaları } \\
\text { gerektiğini anlatır. Evde yapılması için ek çalışmalar gönderirim”. }\end{array}$ \\
\hline Yeterli & 23 & $\begin{array}{l}\text { K12: "Ne kadar olmasl gerektiğinin sınırını ayarlar, hatırlatıcı materyal koyardım ve } \\
\text { unutan çocukların masalarına düzgün oturuş pozisyonunun resmini yapıştırırdım”. } \\
\text { K44: "Çocuklar arasındaki bireysel farklılıklar dikkate alınmalı bence. Masada } \\
\text { kağıtta kendi bedeni arasındaki mesafeyi ayarlamada zorlanan çocuklara } \\
\text { hissettirmeden doğru mesafeyi ayarlamak için oyun etkinliği yapardım”. }\end{array}$ \\
\hline $\begin{array}{l}\text { Örnek } \\
\text { Niteliğinde }\end{array}$ & 2 & $\begin{array}{l}\text { K40: "Rehber öğretmen ile konuşarak bu durumun ne derece normal olduğu hakkında } \\
\text { bilgi sahibi olurdum. Normalse yılsonuna kadar çalışmalarıma devam ederdim. } \\
\text { Değilse gereken desteği alırdım”. }\end{array}$ \\
\hline Kodlanamayan $^{1}$ & 17 & - \\
\hline
\end{tabular}

Tablo 7 incelendiğinde, katılımcıların çoğunluğunun (N:23) sabırlı olma özelliğini

yeterli düzeyde sergilediği görülmektedir. Bununla birlikte bir kısım (N:11) katılımcının bu

\footnotetext{
${ }^{1}$ Bazı (N:17) katılımcının cevapları “Sabırlı Olma” özelliği temelinde kodlanamamıştır.
} 
özelliğe ilişkin iyileştirilme ihtiyacında olduğu tespit edilmiştir. Az sayıda katılımcının ise örnek niteliğinde (N:2) açıklamalar yaptıkları görülmektedir.

Tablo 8. Katılımcıların Esnek Olma Özelliğine İliş̧kin Cevapları

\begin{tabular}{|c|c|c|}
\hline Rubrik & $\mathbf{N}$ & Katılımcıların Cevaplarından Örnekler \\
\hline Yetersiz & 24 & $\begin{array}{l}\text { K5: "Yerine başka etkinlik yapar ve havanın uygun olduğu bir gün bahçe etkinliğini } \\
\text { yapardım". } \\
\text { K35: "Havanın iyi olduğu ileriki bir gün yapardım". }\end{array}$ \\
\hline $\begin{array}{l}\text { İyileştirilme } \\
\text { İhtiyacı }\end{array}$ & 1 & $\begin{array}{l}\text { K30: “Çocuklara havanın yağmurlu olmasından dolayı dışarı çıkamadı̆̆ımızı ancak } \\
\text { etkinliğimizi sınıf içinde de yapabileceğimizi söylerim. Etkinliği çocuklarla birlikte } \\
\text { drama şeklinde uygularız ve havanın uygun olduğu ilk fırsatta dışarı çıkarız”. }\end{array}$ \\
\hline Yeterli & 25 & $\begin{array}{l}\text { K13: "Çok yağmıyorsa giydirip etkinliğimi yaptırırdım. Ya da geniş bir salonum varsa } \\
\text { yaprakları toplar salona dağıtır ve çocuklara orada toplatırdım”. } \\
\text { K24: "Hemen etkinliği sınıfa alır kartondan yapraklar keser toplatırdım ĕger yapraklar } \\
\text { kuru ise bahçeden topladı̆̆ım yapraklarla bu etkinliği gerçekleştirirdim”. }\end{array}$ \\
\hline $\begin{array}{l}\text { Örnek } \\
\text { Niteliğinde }\end{array}$ & 4 & $\begin{array}{l}\text { K11: "Montlart ya da şemsiyelerini alarak kısa süreli de olsa bahçede yaprak } \\
\text { toplamalarını isterdim". }\end{array}$ \\
\hline
\end{tabular}

Tablo 8 incelendiğinde, katılımcıların çoğunluğunun (N:25) esnek olma özelliğini

yeterli düzeyde sergiledikleri görülmektedir. Bununla birlikte bir diğer çoğunluktaki (N:24) katılımcının bu özelliği yetersiz düzeyde sergiledikleri tespit edilmiştir. Az sayıda (N:4) katılımcının ise örnek niteliğinde açıklamalar yaptıkları ve iyileştirilme ihtiyacında oldukları (N:1) görülmektedir.

Tablo 9. Katılımcıların Farklılıklara Saygı Duyma Özelliğine İlişkin Cevapları

\begin{tabular}{|c|c|c|}
\hline Rubrik & $\mathbf{N}$ & Katılımcıların Cevaplarından Örnekler \\
\hline Yetersiz & 20 & $\begin{array}{l}\text { K10: “Gülbala'nın sınıfta olmadı̆̆ bir gün diğer çocuklara onun bizlerden farklı } \\
\text { olduğunu,farklı bir yerden geldiğini o yüzden farklı konuştuğunu söylerim. Daha sonra } \\
\text { Gülbala ya yardımcı olmalarını onunla sık sık sohbet ederek bizim dilimizi de } \\
\text { öğretmelerini isterim”. } \\
\text { K19: "Önce çocuklara gülmeyin diye bir ikazda bulunurdum. Gülbalanın sınıfta } \\
\text { olmadığı bir gün çocuklara Gülbala'nın konuşmaları esnasında bizden farklı sözcükler } \\
\text { kullanmasının nedeninin başka bir ülkeden gelmiş olması olduğunu, onun zamanla } \\
\text { Türkçeyi bizim yardımımızla doğru konuşacağını ve bizlerin ona güldügünde } \\
\text { üzülebileceğini söylerdim”. } \\
\text { K31: "Gülbala' nın yeni bir ülkeye, yeni bir dile alışma aşamasında olduğunu } \\
\text { arkadaşlarının ona gülmesinin onda çekingenlik oluşturabileceğini, gülmek yerine } \\
\text { söylediği şeyin Türkçesini ifade etmesine yardımcı olurlarsa onun çok sevineceğini } \\
\text { söylerdim”. }\end{array}$ \\
\hline $\begin{array}{l}\text { İyileştirilme } \\
\text { İhtiyacı }\end{array}$ & 14 & $\begin{array}{l}\text { K33: “Farklı kültürlere ait etkinlikler planlanarak bu farklılıkların çocuklara daha } \\
\text { anlaşılır gelmesini sağlarım”. } \\
\text { K45: "Yabancı ögrenci ile ilgili sınıfa ilk girdiği anda bilgilendirme yapardım. Onun } \\
\text { farklı bir ülkeden geldiğini bizimle farklı bir dil konuştuğunu ifade ederdim”. }\end{array}$ \\
\hline Yeterli & 16 & $\begin{array}{l}\text { K14: “Gülbala’ya nezaket sözcüklerin Türkçesini, diğer çocuklara ve bana da } \\
\text { Gülbala'nın nezaket sözcüklerin Azericesini ögretmesini isterdim”. } \\
\text { K26: “Çocuklara farklılıkların güzel olduğundan bahseder, çeşitli şive, lehçe örnekleri } \\
\text { verir, farklllıkların bizi güzelleştirdiğinden bahsederdim. Bende Gülbala gibi birkaç } \\
\text { kelime söylerdim”. }\end{array}$ \\
\hline $\begin{array}{l}\text { Örnek } \\
\text { Niteliğinde }\end{array}$ & 4 & $\begin{array}{l}\text { K11: “Azerbaycan hakkında çocuklarla birlikte birkaç video izler. Orda yaşayan } \\
\text { insanların konuşmalarına dikkat çekerek insanların ülkelerinde farklı diller kullandığ } \\
\text { konusunda çocuklarla sohbet ederdim. Çocuklar bu duruma alışana kadar Gülbala ile } \\
\text { konuşmalarımda onun kullandığı kelimelere de yer verirdim”. }\end{array}$ \\
\hline
\end{tabular}

Tablo 9 incelendiğinde, katılımcıların çoğunluğunun (N:20) farklılıklara saygı duyma özelliğini yetersiz düzeyde sergiledikleri görülmektedir. Bununla birlikte bir diğer çoğunluktaki 
(N:16) katılımcının bu özelliği yeterli düzeyde sergilediği ve iyileştirilme ihtiyacında olduğu (N:14) tespit edilmiştir. Az sayıda katılımcının ise örnek niteliğinde (N:4) açıklamalar yaptıkları görülmektedir.

Tablo 10. Katılımcıların Yaratıcı Olma Özelliğine İlişkin Cevapları

\begin{tabular}{|c|c|c|}
\hline Rubrik & $\mathbf{N}$ & Katılımcıların Cevaplarından Örnekler \\
\hline Yetersiz & 4 & $\begin{array}{l}\text { K10: "Şekiller şarkısını açarım aynı zamanda şarkının slaytını da açarım hem görsel } \\
\text { hem işitsel olarak kavramı vermiş olurum müzik etkinliği ile beraber". }\end{array}$ \\
\hline $\begin{array}{l}\text { İyileştirilme } \\
\text { İhtiyacı }\end{array}$ & 34 & $\begin{array}{l}\text { K7: "Sınıfa kare nesneler getirerek müzik eşliğinde nesneleri göstererek ve çocuklara } \\
\text { dokundurarak karenin özelliklerini anlatırdım. Daha sonrasında çocuklarla grup } \\
\text { oluşturup kare şeklini oluştururduk. Kare şekliyle ilgili hikaye oluşturup sınıfta } \\
\text { anlatmalarına firsat verirdim”. } \\
\text { K34: "Hem görsel hem işitsel olan bir etkinliği anlatan bir slayt ve şarkısını söyleyen } \\
\text { bir etkinlik hazırlarım". } \\
\text { K49: "Çocukların bütün duyularına hitap edecek şekilde bir etkinlik hazırlarım". }\end{array}$ \\
\hline Yeterli & 16 & $\begin{array}{l}\text { K14: "Çocukların vücutlarını kullanarak kare şekli oluşturarak daha önceden } \\
\text { oluşturduğumuz kare şarkısını söylemeleri etkinliği yapardım”. } \\
\text { K43: "Hem işitsel hem ellerini kullandıkları bir etkinlik tasarlardım. Sınıfın farkll } \\
\text { yerlerine kare şeklindeki kartonlar asardım. Kare avına çıkılırdı. Her kare } \\
\text { görüldügünde "4 kenarım var, } 4 \text { köşem var benim. Ben kareyim” cümlesi söylenir } \\
\text { sınıftaki çocuklarla. Yere } 4 \text { çocuk yatırıp kare yapılabilir”. }\end{array}$ \\
\hline
\end{tabular}

Tablo 10 incelendiğinde, katılımcıların çoğunluğunun (N:34) yaratıcı olma özelliğine ilişkin iyileştirme ihtiyacında olduğu görülmektedir. Bir diğer çoğunluktaki (N:16) katılımcının bu özelliği yeterli düzeyde sergiledikleri tespit edilmiştir. Az sayıda (N:4) katılımcının ise bu özelliği yetersiz düzeyde sergilediği görülmektedir.

Tablo 11. Katılımcıların Otantik Olma Özelliğine İlişkin Cevapları

\begin{tabular}{|c|c|c|}
\hline Rubrik & $\mathbf{N}$ & Katılımcıların Cevaplarından Örnekler \\
\hline Yetersiz & 1 & $\begin{array}{l}\text { K42: “Değerler eğitimi etkinliklerinde sabır kavramını ĕ̌er vermişsem hatırlatma } \\
\text { yaparım. Ĕger henüz vermemişsem kısaca etkinliğe başlamadan önce yönergelerimi } \\
\text { veririm. Sabırsız ve aceleci davrandığımızda bir şeylerin ters gideceğini söylerim”. }\end{array}$ \\
\hline $\begin{array}{l}\text { İyileştiril } \\
\text { İhtiyacı }\end{array}$ & 20 & $\begin{array}{l}\text { K12: "Tekrar aramasını ĕger bulamazsa önce malzemelerinden sorumlu olduğunu } \\
\text { hatırlatır ve arkadaşlarından ödünç alması gerektiğini söylerim". } \\
\text { K16: "Ahmet'e boya malzemelerinin bulması için biraz daha süre vermek konusunda } \\
\text { ögrencilerime danışırdım. Çünkü Ahmet ararken onların beklemesi gerekecek". }\end{array}$ \\
\hline Yeterli & 33 & $\begin{array}{l}\text { K35: "Boya malzemelerini arayalım derdim. Bütün çocuklarla Ahmet'in boyalarını } \\
\text { arardım. Bulunamazsa çocukların boyalarını paylaşmalarını sağlamak için çözüm } \\
\text { üretmelerini să̆lardım”. } \\
\text { K40: "Önce masada bekleyen çocukları sakinleştirerek sabırlı olmalarını isterim. } \\
\text { Ardından Ahmet ile beraber boyaların nerede olabileceğine bakarım. Bulamazsam bir } \\
\text { arkadaşı ile ortak kullanmasını sağlarım”. } \\
\text { K50: "Öncelikle etkinliğe hep birlikte başlayacağımız konusunda sınıfı bilgilendiririm. } \\
\text { Daha sonra Ahmet'in boyasını bulmaya yardımcı olurum ve eşyalarımızı kendi dolabımıza } \\
\text { düzenli olarak koyarsak her şeyi rahatlıla bulabileceğimiz konusunda sınıf } \\
\text { bilgilendiririm”. }\end{array}$ \\
\hline
\end{tabular}

Tablo 11 incelendiğinde, katılımcıların çoğunluğunun (N:33) otantik olma özelliğini yeterli düzeyde sergiledikleri görülmektedir. Bununla birlikte bu özelliğe ilişkin bir kısım (N:20) katılımcının iyileştirilme ihtiyacında olduğu tespit edilmiştir. Az sayıda (N:1) katılımcının ise yetersiz düzeyde bu özelliği sergilediği görülmektedir.

Tablo 12. Katılımcıların Öğrenmeyi Sevme Özelliğine İlişkin Cevapları 


\begin{tabular}{|c|c|c|}
\hline Rubrik & $\mathbf{N}$ & Katılımcıların Cevaplarından Örnekler \\
\hline Yetersiz & 40 & 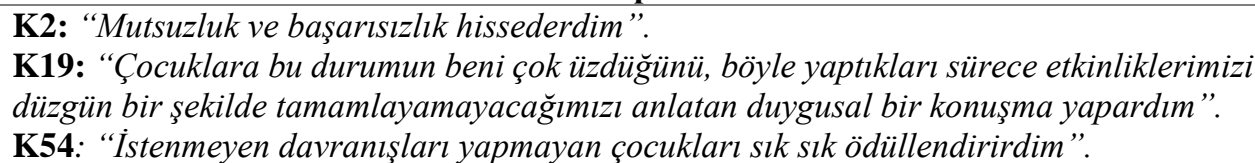 \\
\hline $\begin{array}{l}\text { İyileştirilme } \\
\text { İhtiyacı }\end{array}$ & 8 & $\begin{array}{l}\text { K24: "Uyum sorunu yașayan ögrencime ev ziyareti yapar veli öğretmen iş birliği ile bu } \\
\text { konuyu çözerdim. Hatta gerekli görürsem rehberlik servisinden yardım isterdim" } \\
\text { K37: "Bildiği tüm yolları denedi ise; bu davranıșln sebebini araștırtrdım". }\end{array}$ \\
\hline Yeterli & 6 & $\begin{array}{l}\text { K21: "Farkll yollar arașttrırdım. Tecrübesine güvendiğim öğretmenlere danışırdım”. } \\
\text { K36: "Bilmediğim yolları araştırtrdım". }\end{array}$ \\
\hline
\end{tabular}

özelliğini yetersiz düzeyde sergiledikleri görülmektedir. Bununla birlikte bu özelliğe ilişkin bir kısım (N:8) katılımcının iyileştirilme ihtiyacında olduğu tespit edilmiştir. Az sayıda (N:6) katılımcının ise özelliğe ilişkin örnek niteliğinde açıklamalar yaptıkları görülmektedir.

Tablo 13. Katılımcıların Yüksek Enerjiye Sahip Olma Özelliğine İlişkin Cevapları

\begin{tabular}{|c|c|c|}
\hline Rubrik & $\mathbf{N}$ & Katılımcıların Cevaplarından Örnekler \\
\hline Yetersiz & 23 & $\begin{array}{l}\text { K1: "Şu an müziğin ve eşinin olmadığını söyler evde göstermesini söylerim”. } \\
\text { K13: "Öğrendiğimiz dansın annemize sürpriz olacağını söylerim. Şimdi gösterirsek } \\
\text { sürprizi kaçar derim ve yollarım”. } \\
\text { K47: "Ege'ye şu an ikimizin de eve gitmemiz gerektiğini ve çok yorgun olduğumu } \\
\text { anlayacağl şekilde anlatırdım”. }\end{array}$ \\
\hline $\begin{array}{l}\text { İyileştirilme } \\
\text { İhtiyacı }\end{array}$ & 7 & $\begin{array}{l}\text { K39: "Çok geç bir vakit değilse ve sınıfimı bir sonraki ögretmene teslim etmeyeceksem } \\
\text { Ege ye eş olabilirdim". }\end{array}$ \\
\hline Yeterli & 24 & $\begin{array}{l}\text { K5: "Çok yorgun bile olsam eşi ben olur ve isteğini geri çevirmezdim”. } \\
\text { K26: "Dansını annesine göstermesi için onun eşi olurdum. Böylece çocuğun şevki } \\
\text { kırılmaz ve kendine olan güveni sarsılmazdı". } \\
\text { K40: "Ne kadar yorgun olsam da öğrencimin isteğini yerine getirmeye çalışırım". }\end{array}$ \\
\hline
\end{tabular}

Tablo 13 incelendiğinde, katılımcıların çoğunluğunun (N:24) yüksek enerjiye sahip olma özelliğini yeterli düzeyde sergilediği; bir diğer çoğunluktaki (N:23) katılımcının ise yetersiz düzeyde sergilediği görülmektedir. Bununla birlikte bu özelliğe ilişkin az sayıda (N:7) katılımcının iyileştirilme ihtiyacında olduğu tespit edilmiştir.

Tablo 14. Katılımcıların Mizah Anlayışına Sahip Olma Özelliğine İlişkin Cevapları

\begin{tabular}{|c|c|c|}
\hline Rubrik & $\mathbf{N}$ & Katılımcıların Cevaplarından Örnekler \\
\hline Yetersiz & 12 & $\begin{array}{l}\text { K2: “"Ben böyle seviyorum, farklı olmak istedim.” Derdim. İçimden de bozulurdum } \\
\text { tabii”. } \\
\text { K52: "Kendisinin saçlarını değişiklik olsun diye yaptı̆̆ını herkesin herşeyi beğenme } \\
\text { konusunda aynı fikre sahip olmadığını söylerim. Duygu ve düşüncelerimizi gülmeden de } \\
\text { karşımızdaki kişiye ifade edebileceğimizi belirtirdim”. }\end{array}$ \\
\hline $\begin{array}{l}\text { İyileştirilme } \\
\text { İhtiyacı }\end{array}$ & 22 & $\begin{array}{l}\text { K3: “Bugün kıvırcık kavramını ögreneceğimiz için böyle bir değişiklik yaptım derdim, } \\
\text { güler geçerdim”. } \\
\text { K23: "Beni komik bulmana çok sevindim, saçlarım hangi haliyle daha güzel sence gibi } \\
\text { bir sohbet başlatırdım”. } \\
\text { K50: "Onlarla ben de gülerim. Neden böyle düşündüğünü başka neye benzeyebileceğimi } \\
\text { de sorarım”. }\end{array}$ \\
\hline Yeterli & 14 & $\begin{array}{l}\text { K20: “Ben de onunla beraber gülüp 'bugün sizin için komik olmak istedim' derdim (-)” } \\
\text { K40: “Çocuklarla beraber bu duruma güler, hatta palyaço gibi taklitler yaparak daha } \\
\text { eğlenceli hale getirebilirdim”. }\end{array}$ \\
\hline $\begin{array}{l}\text { Örnek } \\
\text { Niteliğinde }\end{array}$ & 6 & $\begin{array}{l}\text { K4: "Evet ben bugün sizin için palyaço oldum. Yalnız çocuklar burnumu düşürdüm hemen } \\
\text { geçici bir burun yapmamı lazım der ve burnumu kırmızlya boyar yüzüme çiçekler çizer } \\
\text { müzik açarım. Hep birlikte dans ederiz”. }\end{array}$ \\
\hline
\end{tabular}


Tablo 14 incelendiğinde, katılımcıların çoğunluğunun (N:22) mizah anlayışına sahip olma özelliğine ilişkin iyileştirilmeye ihtiyacı olduğu görülmektedir. Bununla birlikte bir diğer çoğunluktaki (N:14) katılımcı bu özelliği yeterli düzeyde sergilerken; bir kısım (N:12) katılımcının yetersiz düzeyde sergilediği tespit edilmiştir. Az sayıda (N:6) katılımcının ise özelliğe ilişkin örnek niteliğinde açıklamalar yaptıkları görülmektedir.

Tablo 15. Öğretmen Özellikleri Arasındaki İlişsi ${ }^{2}$

\begin{tabular}{|c|c|c|c|c|c|c|c|c|c|c|c|}
\hline & 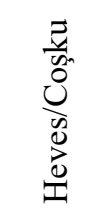 & 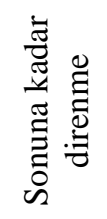 & 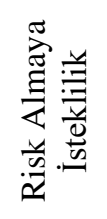 & 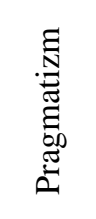 & 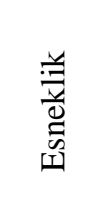 & 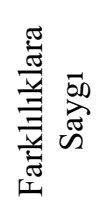 & 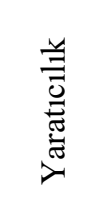 & 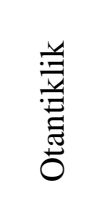 & 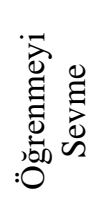 & 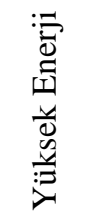 & $\stackrel{\frac{\pi}{\pi}}{\stackrel{\pi}{\Sigma}}$ \\
\hline Heves/Coşku & 1 & & & & & & & & & & \\
\hline $\begin{array}{l}\text { Sonuna Kadar } \\
\text { Direnme }\end{array}$ & -.243 & 1 & & & & & & & & & \\
\hline $\begin{array}{l}\text { Risk Almaya } \\
\text { İsteklilik }\end{array}$ & .243 & .210 & 1 & & & & & & & & \\
\hline Pragmatizm & $-.300^{*}$ & .129 & .118 & 1 & & & & & & & \\
\hline Esneklik & .161 & .142 & -.140 & -.219 & 1 & & & & & & \\
\hline $\begin{array}{l}\text { Farklılıklara } \\
\text { Sayg1 }\end{array}$ & .017 & $.283^{*}$ & .243 & .184 & -.015 & 1 & & & & & \\
\hline Yaratıcılık & .216 & .077 & .071 & -.135 & .063 & .167 & 1 & & & & \\
\hline Otantiklik & -.146 & -.114 & -.232 & -.065 & -.097 & -.082 & .063 & 1 & & & \\
\hline $\begin{array}{l}\text { Öğrenmeyi } \\
\text { Sevme }\end{array}$ & -.119 & -.149 & -.213 & .049 & .255 & -.204 & .073 & .027 & 1 & & \\
\hline Yüksek Enerji & -.148 & -.095 & -.021 & .122 & -.135 & -.215 & $-.345^{*}$ & -.143 & .251 & 1 & \\
\hline Mizah & -.031 & .149 & -.003 & .057 & -.038 & .236 & .040 & .254 & -.107 & .074 & 1 \\
\hline
\end{tabular}

Tablo 15 incelendiğinde, araştırmaya dahil olan öğretmenlerin etkili okul öncesi öğretmeni özelliklerini sergileme düzeyleri arasındaki ilişkiyi belirlemek üzere yapılan Spearman Sıra Farkları Korelasyon analizi sonucunda, hevesli/coşkulu olma ile pragmatist olma puanları ve yaratıcı olma ile yüksek enerjiye sahip olma puanları arasında istatistiksel açıdan $\mathrm{p}<.05$ düzeyinde negatif yönlü anlamlı bir ilişki; sonuna kadar direnme ile farklılıklara saygı gösterme puanları arasında ise istatistiksel açıdan $\mathrm{p}<.05$ düzeyinde pozitif yönlü anlamlı bir ilişki tespit edilmiştir.

\section{Tartışma ve Sonuç}

Okulların işlevi ve eğitimin etkililiğii, uzun yıllardır üzerinde derin tartışmalar yapılan konu başlıklarından bazılarıdır. Okul kültürünün şekillenmesine ve eğitimin etkililiğine olumlu

\footnotetext{
2 “Sabırlı Olma” öğretmen özelliği, bazı katılımcıların (N:17) cevapları ilgili özellik temelinde kodlanamadığı
} için analize dahil edilmemiştir. 
katkı sağlayan önemli öğelerden birisi ise hiç kuşkusuz etkili öğretmenlerdir (Ellett ve Teddlie, 2003). Öğretmen etkililiği konusunda yapılan geniş kapsamlı araştırmalar, genellikle öğretmenlerin aldıkları eğitimin süresinin (Chingos ve Peterson, 2011; Rivkin, Hanushek ve Kain, 2005), lisansüstü derecelerinin (Chingos ve Peterson, 2011; Leigh, 2010), öğretmenlik deneyim yıllarının ${ }^{3}$ ya da yaşlarının (özellikle öğrenci başarısının temel alındığı öğretmen etkililiği çalışmalarında) önemli bir belirleyici olmadığını ortaya koymuştur. Etkili öğretmenliğin olumlu yordayıcılarının ise etkili iletişim (Check, 1986; Korte, Lavin ve Davies, 2013), sonuna kadar direnme (Duckworth, Quinn ve Seligman, 2009), yaşam doyumu (Duckworth, Quinn ve Seligman, 2009) ve mizahın kullanımı (Check, 1986) gibi öğretmenin kişisel özelliklerine ilişkin yapılar olduğu saptanmıştır. Bu bağlamda, bu araştırmada okul öncesi öğretmenlerinin kişisel özellikleri mercek altına alınmıştır. Etkili okul öncesi öğretmenlerinin kişisel özelliklerine ilişkin uzun bir liste oluşturmak mümkündür. Bu listelerden bir tanesi de Colker'a (2008) aittir. Bu araştırma Colker'ın (2008) ortaya koyduğu etkili okul öncesi öğretmeninin 12 özelliği temelinde çerçevelendirilmiş ve okul öncesi öğretmenlerinin bu özellikleri sergileme durumlarının incelenmesinde veri toplama amacıyla, anket türü araçların çeşitli sınırlılıkları göz önünde bulundurularak, alternatif yöntemlerden biri olan kısa hikayelerden yararlanılmasına karar verilmiştir. Kısa hikayelerin veri toplamada tercih edilme nedenleri; öğretmenlerin çoklu ve genişleyen rollerini dikkate almak, çeşitli konularda ve alanlarda farklı öğretmen etkililiğine yol açabilecek bu farklı rolleri ve faktörleri daha doğru bir şekilde yansıtan çalışmaların geliştirilmesine katkı sağlamaktır (Muijs, 2006). Buna paralel olarak bu araştırmada; okul öncesi öğretmenlerinin, etkili okul öncesi öğretmenlerinin kişisel özelliklerine sahip olma durumlarının kısa hikayeler yoluyla incelenmesi ve öğretmen özellikleri arasındaki ilişkinin sınanması amaçlanmıştır.

Araştırmanın ilk amacı doğrultusunda elde edilen bulgular, öğretmenlerin büyük bir kısmının coşkulu olma ve otantik olma özelliğini yüksek oranda ve yeterli düzeyde sergilediğini, buna karşın öğrenmeyi sevme, pragmatist olma (küçük ilerlemelerin farkında olma), farklılıklara saygı gösterme, yaratıcı olma (farklı öğrenme stillerine sahip çocuklar için etkinlik düzenleyebilme) ve mizah anlayışı özelliklerini sergilemede çeşitli iyileştirmelere açık olduklarını göstermiştir. Çocukların içsel motivasyonlarını, dikkatlerini ve hafızalarını yordayan temel öğretmen özelliğinin öğretmen coşkusu olduğuna ilişkin güçlü kanıtların

\footnotetext{
$3 \mathrm{Bu}$ açıdan alanyazında detaylı incelemeler yapılmıştır: Özellikle öğretmenlerin kariyerlerinin erken dönemlerinde, ikinci yıl deneyimiyle etkililiklerinin arttı̆̆ 1 ancak üçüncü yılla birlikte etkliliklerinin sabitlendiği ve deneyimlerinin ilerleyen yıllarında etkililik düzeylerinin düşüşe geçtiği yönünde bulgular (Leigh, 2010) mevcuttur.
} 
(Keller ve diğ., 2014; Patrick, Hisley ve Kempler, 2000; Wood, 1999) varlığ1 düşünüldüğünde, bu araştırma sonucunda elde edilen bulgu oldukça umut vericidir. Ancak öğretmen coşkusu konusunda bu araştırmadan elde edilen bu bulguyu, Türkiye Cumhuriyeti’nin devlet okullarında çalışabilme konusunda bir kriter olarak belirlediği Kamu Personeli Seçme Sınavı (KPSS) etkisi ile birlikte ele almakta fayda olduğu düşünülebilir. Çünkü bu araştırma, KPSS sonucunda MEB'e bağlı devlet okullarında görev yapmakta olan öğretmenler ile sınırlandırılmıştır. KPSS sonucunda uygun bir puan alarak MEB'e bağlı okullarda görev yapmaya hak kazanan öğretmenlerin meslekte kalma isteği, bu anlamda coşkusunun, özel sektörde görev yapmakta olan öğretmenlerin meslekte kalma isteği ile karşılaştırılmasına dayalı olarak tasarlanacak gelecekteki araştırmalar, öğretmen coşkusunda KPSS sınavının belirleyici bir faktör olup olmadığını ortaya koyacaktır. Bunun yanı sıra bu araştırmada öğretmenlerin iyileştirilmeye açık olduğu özellikler bağlamında elde edilen sonuçlar oldukça dikkat çekici ve üzerinde tartışmaya değer konulardır. Bu tartışmanın gerçekleştirilmesinde, alan yazındaki diğer araştırma bulgularının desteğine ihtiyaç duyulmaktadır. Ancak alan yazındaki araştırmalar çelişkili bilgiler sunmaktadır. Örneğin, okul öncesi öğretmenleri “MEB Okul Öncesi Öğretmenleri Özel Alan Yeterlikleri” bakımından öğretmenlerin kendilerini gelişim alanlarının tamamında yeterli gördüklerini ifade ederken (Bağ ve Çeviker Ay, 2017), çocuğu tanıma teknikleri (Aktan Kerem ve Cömert, 2006), çocuk ruh sağlığı (Uşun ve Cömert, 2003), yaratıcı etkinlikler düzenleme (Uşun ve Cömert, 2003) ve erken müdahale programları (Doğan ve Tatık, 2014) konularında hizmet içi eğitime gereksinim duyduklarını dile getirmişlerdir. Ancak Türkiye Okul Öncesi Eğitimini Geliştirme Derneği’nin (TOÖEGD) İyi Bir Başlangıç İçin Öğretmen Niteliği Çalıştayı Hizmetteki Öğretmenin Niteliğini Artırma Çalışma Raporu’nda değinilen öğretmenin kişisel gelişimine ilişkin sorunlar, bu araştırmada elde edilen bulgularla paralellik taşımaktadır (TOÖEGD, 2017). Bu raporda öğretmenin öğrenme merakını devam ettirememesi, öğretmenlerin iç motivasyonunu yüksek tutamaması, kendilerini değerli hissedememeleri, yeniliğe ayak uyduramamaları, çalıştıkları sosyo-kültürel çevrenin özelliklerini bilmemeleri, kendini geliştiren-geliştirmeyen öğretmen ayrımının olmaması, öğretmenlerin performansa dayalı olarak değerlendirilmemesi, öğretmenin çocuğa bakış açısı ile ilgili sorunlar, öğretmenlerin işini severek yapmamaları, MEB'in öğretmenlerin kişisel durum ve sorunlarını dikkate almaması konuları dile getirilmiştir.

Öğretmenlerin sergiledikleri kişisel özellikleri arasındaki ilişkiler de, hangi özelliklerin iyileştirilmesiyle büyük bir değişim yaratılabileceğine 1 şı tutması bakımından oldukça önemlidir. Bu bağlamda araştırmanın ikinci amacı doğrultusunda elde edilen bulgularda, 
öğretmenlerin yüksek enerji düzeyleri ile yaratıcı olma düzeyleri ve öğretmenlerin coşkulu olma düzeyleri ile pragmatist olma düzeyleri arasında negatif yönlü anlamlı ilişkiye; sonuna kadar direnme düzeyleri ile farklılıklara saygı gösterme düzeyleri arasında pozitif yönlü anlamlı ilişkiye rastlanmıştır. Öğretmen coşkusunun temel yordayıcılarından birinin içsel motivasyon olduğu ve öğretmenin pragmatist olmasının çocuklardaki küçük ilerlemeleri değerli görme ile ilgili olduğu birlikte düşünüldüğünde, öğretmen coşkusu ile pragmatizmi arasındaki negatif yönlü ilişkinin şaşırtıcı olmadığını belirtmek gerekmektedir. Çünkü öğretmenlerin coşkusu, güdülenememe durumları ile negatif ilişki içindedir (Orosz ve diğ. 2015). Bu bağlamda, pragmatizm özelliğini sergileme düzeyi düşük öğretmenlerin, çocukların küçük ilerlemelerini yeterli görmediklerini, bu nedenle kendilerini etkili olarak değerlendirmediklerini ve güdülenemediklerini düşünmek mümkündür.

Araştırmanın ikinci amacı doğrultusunda elde edilen bir başka bulgu ise öğretmenlerin sonuna kadar direnme düzeyleri ile farklılıklara saygı duyma düzeyleri arasında pozitif yönlü anlamlı ilişkidir. Günümüz sınıflarında, farklı sosyal kültürel ve ekonomik arka planlara sahip çocukların gelişimlerini destekleyebilen öğretmenlere ihtiyaç duyulmaktadır. Farklılıklara sayg1 gösteren ve farklılıkları takdir ile karşılayan öğretmenler, sadece kuramsal olarak değil, aynı zamanda kültüre duyarlı pedagojiyi de kullanmaktadırlar. Öğretmenler, tüm çocukların, kültürel, sosyal ve ekonomik altyapılarına bakmaksızın, öğrenme fırsatlarını en üst düzeyde değerlendiren ve çocukların tüm alanlardaki gelişimlerini destekleyen bir sınıf kültürü oluştururlar (Richards, Brown ve Forde, 2007). Bu anlayışa sahip öğretmenlerin, çocukların çıkarları söz konusu olduğunda imkanları zorlayacak öğretmenler olacağı açıktır. Çocukların savunuculuğunu üstlenmek ve iyi oluşları için mücadele etmek çoğulcu bir bakış açısıyla ilişkilidir.

Araştırmanın bir diğer sonucu da öğretmenlerin yaratıcı olma düzeyleri ile yüksek enerji düzeyleri arasında negatif yönlü anlamlı ilişkidir. Bu araştırmada ele alınan yaratıcılık kavramı, öğretmenin bir birey olarak kişisel yaratıcılığını ifade etmemektedir. Colker'ın (2008) sınıflamasına göre, öğretmenlerin eğitim sürecini planlarken öğrenme stilleri veya ilgileri farklı olan çocukların öğrenme ihtiyaçlarını karşılayacak ortak etkinlikler planlayabilmesi, öğretmenin yaratıcı olma özelliğini ifade etmektedir. Bilindiği üzere öğrenme stilleri, aynı öğretim yönteminin bazı çocuklar için etkili, diğer çocuklar için etkisiz kılan kişisel özellikler kümesidir (Dunn, Beaudry ve Klavas, 2002). Bu anlamda, öğretmenin tüm çocukların öğrenme stillerini göz önünde bulundurarak, tüm çocukların öğrenme ihtiyaçlarını bu stiller doğrultusunda destekleyebilmesi ancak öğretmenin sınıfındaki tüm çocukların öğrenmelerini 
önemsemesi ile mümkün olabilmektedir. Bir diğer ifade ile öğretmenin yalnızca sınıfında yaygın olan öğrenme stili temelinde etkinlikler üretmesi, eğitim sürecini planlarken yaratıcı olma özelliğini sergilemediğini göstermektedir. $\mathrm{Bu}$ araştırma sonucunda öğretmenlerin sergilediği yaratıcı olma özelliği ile yüksek enerji sergileme özelliği arasında negatif yönlü bir ilişki olduğu saptanmıştır. Buna göre sınıfındaki tüm çocukların öğrenme stillerini dikkatine almayan bir öğretmenin yüksek enerji sergileyebildiğini söylemek mümkündür. Bunun tam tersini belirtmek de yanlış olmayacaktır.

\section{Öneriler}

Araştırmada okul öncesi öğretmenlerinin öğrenmeyi sevme, pragmatist olma, farklılıklara saygı gösterme, yaratıcı olma ve mizah anlayışı özelliklerini sergilemede çeşitli iyileştirmelere açık oldukları görülmüştür. Okul öncesi öğretmenlerinin iyileştirilmeye ihtiyacı olduğu bu özelliklerde yeterliliği artırmak için çeşitli eylem planlarının (lisans dersleri, hizmet içi eğitim, mentörlük uygulaması gibi) geliştirilmesi ve hangi planların etkili olacağı konusunda deneysel araştırmalar yapılması önerilebilir.

Araştırmada okul öncesi öğretmenlerinin öğretmen özelliklerini sergileme düzeyleri kısa hikayeler yolu ile belirlenmeye çalışılmıştır. Yapılacak yeni araştırmalarda nitel veya nicel farklı araştırma yöntem ve teknikleri ile etkili öğretmen özellikleri araştırılabilir.

Araştırma maksimum çeşitlilik örneklemesi bağlamında 54 gönüllü okul öncesi öğretmeni ile gerçekleştirilmiştir. Farklı örneklem seçim yöntemleri ile çalışma grubunda yer alan öğretmen sayısı genişletilerek yeni araştırmalar daha kapsamlı hale getirilebilir. Böylelikle öğretmenlerin iyileştirmeye ihtiyacında olduğu özellikler ile bu özellikler arasındaki nedensel ilişkiler de açıklığa kavuşturulabilir. Bununla birlikte bu araştırmada, Milli Eğitim Bakanlığı'na bağlı devlet okullarında çalışmakta olan okul öncesi öğretmenleri yer almıştır. Araştırma bulguları arasında öğretmenlerin fiziksel ya da finansal güçlükleri ortadan kaldırma çabalarının ya da ilgili durumu iyileştirmeye yönelik girişimlerini ifade eden hevesli/coşkulu olma özelliğini yeterli düzeyde sergiledikleri saptanmıştır. Bu husustan yola çıkarak örneklemi özel kurumlarda çalışan okul öncesi öğretmeni olan yeni araştırmalarla etkili okul öncesi öğretmen özellikleri sınanabilir. Yapılacak ek araştırmalar ile okul öncesi öğretmenlerin cinsiyet, çalıştığı kurum, mezuniyet, sınıfındaki çocuk sayısı gibi faktörlerin öğretmen özellikleri üzerindeki etkisi belirlenebilir.

Okul öncesi öğretmenlerin ve hizmet öncesi öğretmenlerin etkili okul öncesi öğretmen özelliklerine ilişkin düzeyleri belirlenerek karşılaştırma çalışmaları yapılabilir. Yurt içi 
araştırmalar incelendiğinde etkili okul öncesi dönem öğretmenin özelliklerine ilişsin daha fazla sayıda araştırmaya ve kanıtlara dayalı bulgulara ihtiyaç olduğu görülmüşstür.

\section{Makalenin Bilimdeki Konumu}

Temel Eğitim/ Okul Öncesi Eğitimi

\section{Makalenin Bilimdeki Özgünlüğü}

Alan yazında öğretmen etkililiği ve etkili öğretmen özelliklerinin mercek altına alındığg çalışmalar incelendiğinde, araştırmaların yaygın olarak etkili öğretmenlerin mesleki özelliklerine odaklandıkları görülmektedir. Etkili okul öncesi öğretmenlerinin kişisel özelliklerine ilişkin ise yeterli çalışmanın olmadığı tespit edilmiştir. Bu nedenle, etkili okul öncesi öğretmenlerinin 12 kişisel özelliği tüm boyutlarıyla incelemeye alınmıştır. Öğretmen özellikleri çok parçalı bir yapıya sahip olması nedeniyle, öğretmenlerin bu özellikleri sergileme düzeyleri karmaşık ve anlaşılması kolay olmayan yapıların analiz edilmesinde sistemli ve metodolojik bir yol sunan kısa hikayelerin kullanımı ile ortaya koyulmuştur.

\section{Kaynaklar}

Aktan Kerem, E., \& Cömert, D. (2006) Siirt ilinde okul öncesi eğitim sorunlarının tespitine yönelik öğretmen görüşlerinin incelenmesi. Milli Eğitim Dergisi, 34(170), 1-16.

Angelides, P., \& Gibbs, P. (2006). Supporting the continued professional development of teachers through the use of vignettes. Teacher Education Quarterly, 33(4), 111-121.

Ay, Ş., \& Yurdabakan, İ. (2015). Öğretmen adaylarına göre etkili öğretmen özellikleri ve bu özellikler açısından öz-yeterlik algıları. Mehmet Akif Ersoy Üniversitesi Eğitim Fakültesi Dergisi, 1(33), 148-166.

Bağ, C., \& Ay Çeviker, Ş. (2017). Okul öncesi öğretmenlerinin öğretmen yeterlikleri ve hizmet içi eğitim ihtiyaçları. Abant İzzet Baysal Üniversitesi Sosyal Bilimler Enstitüsü Dergisi, 17(1), 289-312.

Baum, A. C., \& King, M. A. (2006). Creating a climate of self-awareness in early childhood teacher preparation programs. Early Childhood Education Journal, 33(4), 217-222. https://doi.org/10.1007/s10643-005-0050-2.

Bean-Mellinger B. (2018). Qualities of a good teacher in early childhood development. Erişim Tarihi: 28.11.2018, https://work.chron.com/qualities-good-teacher-early-childhooddevelopment-8694.html.

Boulton, M. J., Hardcastle, K., Down, J., Fowles, J., \& Simmonds, J. A. (2014). A comparison of preservice teachers' responses to cyber versus traditional bullying scenarios: 
Similarities and differences and implications for practice. Journal of Teacher Education, 65(2), 145-155. https://doi.org/10.1177/0022487113511496.

Bozkuş, K., \& Taştan, M. (2016). Teacher opinions about qualities of effective teaching. Pegem Journal of Education and Instruction, 6(4), 469-490. http://dx.doi.org/10.14527/pegegog.2016.023.

Breault, R. A. (2013). "She Was Great, but...": Examining preservice recollections of favorite and most effective teachers. Professional Educator, 37(1), n1.

Bryant, J., Comisky, P. W., Crane, J. S., \& Zillmann, D. (1980). Relationship between college teachers' use of humor in the classroom and students' evaluations of their teachers. Journal of educational psychology, 72(4), 511-519. http://dx.doi.org/10.1037/0022-0663.72.4.511.

Burden, P. R. (1980). Teachers 'perceptions of the characteristics and influences on their personal and professional development. Manhattan, KS: Author. (ERIC Document Reproduction Service No. ED 198087).

Büte, M., \& Balcı, A. F. (2010). Bağımsız anaokulu yöneticilerinin bakış açısından okul yönetimi süreçlerinin işleyişi ve sorunlar. Kuram ve Uygulamada Eğitim Yönetimi Dergisi, 16(4), 485-511.

Büyüköztürk, Ş., Kılıç Çakmak, E., Akgün, Ö.E., Karadeniz, Ş., \& Demirel, F. (2013). Ĕgitimde Bilimsel Araştırma Yöntemleri (25. baskı). Ankara: Pegem Akademi.

Can, N. (2004). Öğretmenlerin geliştirilmesi ve etkili öğretmen davranışları. Erciyes Üniversitesi Sosyal Bilimler Enstitüsü Dergisi, 16(1), 103-119.

Cartwright, S. (1999). What makes good early childhood teachers?. Young Children, 54(4), 47.

Check, J. F. (1986). Positive traits of the effective teacher--negative traits of the ineffective one. Education, 106(3), 326-333.

Chingos, M. M., \& Peterson, P. E. (2011). It's easier to pick a good teacher than to train one: Familiar and new results on the correlates of teacher effectiveness. Economics of Education Review, 30(3), 449-465. https://doi.org/10.1016/j.econedurev.2010.12.010.

Christensen, L. B., Johnson, R.B., \& Turner, L.A. (2015). Araştırma yöntemleri: Desen ve analiz (A. Aypay, çev. ed.). Ankara: Anı Yayıncılık.

Colker, L. J. (2008). Twelve characteristics of effective early childhood teachers. YC Young Children, 63(2), 68-73. 
Çakmak, M., \& Gündüz, M. (2018). Pre-service ELT teachers' perceptions of characteristics of effective teachers. Gazi University Journal of Gazi Educational Faculty (GUJGEF), 38(1), 359-383.

Doğan, B., \& Tatık, R. Ş. (2014). Okul öncesi öğretmenlerinin hizmet içi eğitim ihtiyaçlarının belirlenmesi. International Journal of Social Science, (27), 521-539.

Dinçer, A., Göksu, A., Takkaç, A., \& Yazıcı, M. (2013). Common characteristics of an effective english language teacher. Online Submission, 4(3), 1-8.

Duckworth, A. L., Quinn, P. D., \& Seligman, M. E. (2009). Positive predictors of teacher effectiveness. The Journal of Positive Psychology, 4(6), 540-547. https://doi.org/10.1080/17439760903157232.

Dunn, R., Beaudry, J. S., \& Klavas, A. (2002). Survey of research on learning styles. California Journal of Science Education, 2(2), 75-98.

Egyed, C. J., \& Short, R. J. (2006). Teacher self-efficacy, burnout, experience and decision to refer a disruptive student. School Psychology International, 27(4), 462-474. https://doi.org/10.1177/0143034306070432.

Ellett, C. D., \& Teddlie, C. (2003). Teacher evaluation, teacher effectiveness and school effectiveness: Perspectives from the USA. Journal of Personnel Evaluation in Education, 17(1), 101-128.

Erdiller, Z. B., \& Mcmullen, M. B. (2003). Turkish teachers' beliefs about developmentally appropriate practices in early childhood education. Hacettepe Üniversitesi Ĕgitim Fakültesi Dergisi, 25(25), 84-93.

Evans, S. C., Roberts, M. C., Keeley, J. W., Blossom, J. B., Amaro, C. M., Garcia, A. M., Stough, C. O., Canter, K. S., Robles, R., \& Reed, G. M. (2015). Vignette methodologies for studying clinicians’ decision-making: validity, utility, and application in ICD-11 field studies. International Journal of Clinical and Health Psychology, 15(2), 160-170. https://doi.org/10.1016/j.ijchp.2014.12.001.

Finch, J. (1987). Research Note: The Vignette Technique in Survey Research. Sociology 21(1): 105-114. https://doi.org/10.1177/0038038587021001008.

Glesne, C. (2012). Nitel araştırmaya giriş. (A. Ersoy, \& P. Yalçınoğlu, Çev.) Ankara: Anı Yayınc1lik.

Gorham, J., \& Christophel, D. M. (1990). The relationship of teachers' use of humor in the classroom to immediacy and student learning. Communication education, 39(1), 46-62. https://doi.org/10.1080/03634529009378786. 
Hegde, A. V., \& Cassidy, D. J. (2009). Teachers' beliefs and practices regarding developmentally appropriate practices: a study conducted in India. Early Child Development and Care, 179(7), 837-847. https://doi.org/10.1080/03004430701536491.

Huebner, S. (1991). Bias in special education decisions: The contribution of analogue research, School Psychology Quarterly 6(1): 50-65. http://dx.doi.org/10.1037/h0088240.

Jeffries, C., \& Maeder, D. W. (2005). Using vignettes to build and assess teacher understanding of instructional strategies. Professional Educator, 27, 17-28.

Jeffries, C., \& Maeder, D. W. (2006). Using instructional and assessment vignettes to promote recall, recognition, and transfer in educational psychology courses. Teaching Educational Psychology, 1 (2), 1-19.

Jeffries, C., \& Maeder, D. W. (2009). The effect of scaffolded vignette instruction on student mastery of subject matter. The Teacher Educator, 44(1), 21-39. https://doi.org/10.1080/08878730802522262.

Jorde-Bloom, P. (1988). Closing the gap: An analysis of teacher and administrator perceptions of organizational climate in the early childhood setting. Teaching and Teacher Education, 4(2), 111-120.

Keller, M. M., Goetz, T., Becker, E. S., Morger, V., \& Hensley, L. (2014). Feeling and showing: A new conceptualization of dispositional teacher enthusiasm and its relation to students' interest. Learning and Instruction, 33, 29-38. https://doi.org/10.1016/j.learninstruc.2014.03.001.

Korte, L., Lavin, A., \& Davies, T. (2013). An investigation into good teaching traits. Journal of Learning in Higher Education, 9(1), 141-150.

Külekçi, G. (2018). Identifying the perceptions of prospective English language teachers on characteristics of effective teachers: Who is the ideal teacher?. Novitas-ROYAL (Research on Youth and Language), 12(1), 1-15.

Landis, J. R., \& Koch, G. G. (1977). The measurement of observer agreement for categorical data. Biometrics, 33(1), 159-174.

Leigh, A. (2010). Estimating teacher effectiveness from two-year changes in students' test scores. Economics of $\quad$ Education $\quad$ Review, 29(3), $\quad$ 480-488. https://doi.org/10.1016/j.econedurev.2009.10.010.

Liebovich, B., \& Adler, S. M. (2009). Teaching advocacy in early years initial teacher education programmes. Forum, 51(1), 25-34.http://dx.doi.org/10.2304/forum.2009.51.1.25. 
Lindamood, J. B. (1995). Teachers as child advocates: A continuum of involvement. Day Care and Early Education, 22(4), 23-24. https://doi.org/10.1007/BF02361374.

Liu, S., Liu, C., Stronge, J., \& Xu, X. (2016). Teacher characteristics for success in the classroom: Chinese principals’ perceptions for hiring decisions. Asia Pacific Education Review, 17(1), 107-120. https://doi.org/10.1007/s12564-015-9412-7.

Marsh, C. (1982) The Survey Method. London: Allen and Unwin.

Miles, M. (1990). New methods for qualitative data collection and analysis: vignettes and prestructured cases. International Journal of Qualitative Studies in Education, 3(1), 3751. https://doi.org/10.1080/0951839900030104.

Morrison, G. S. (2004). Early childhood education today. Upper Saddle River, N.J.: Merrill/Prentice Hall.

Morrow, J. R., Mood, D. P., Disch, J. G., \& Kang, M. (2016). Measurement and evaluation in human performance. 5th Edition. Champaign: Human Kinetics.

Muijs, D. (2006). Measuring teacher effectiveness: Some methodological reflections. Educational Research and Evaluation, 12(1), 53-74. https://doi.org/10.1080/13803610500392236.

Orosz, G., Tóth-Király, I., Bőthe, B., Kusztor, A., Kovács, Z. Ü., \& Jánvári, M. (2015). Teacher enthusiasm: A potential cure of academic cheating. Frontiers in psychology, 6, 318, 1-12. https:// doi.org/10.3389/fpsyg.2015.00318.

Özdemir, S., Sezgin, F., Kaya, Z., \& Recepoğlu, E. (2011). İlköğretim okulu öğretmenlerinin stresle başa çıkma tarzları ile kullandıkları mizah tarzları arasındaki ilişki. Kuram ve Uygulamada Eğitim Yönetimi Dergisi, 17(3), 405-428.

Özkan, M., \& Arslantaş, H. İ. (2013). Etkili öğretmen özellikleri üzerine sıralama yöntemiyle bir ölçekleme çalışması. Trakya University Journal of Social Science, 15(1), 311-330.

Patrick, B. C., Hisley, J., \& Kempler, T. (2000). “What's everybody so excited about?”: the effects of teacher enthusiasm on student intrinsic motivation and vitality. The Journal of Experimental Education, 68(3), 217-236. https://doi.org/10.1080/00220970009600093.

Rentzou, K., \& Sakellariou, M. (2011). Greek pre-service kindergarten teachers’ beliefs about and practices of developmentally appropriate practices in early childhood education. Early Child Development and Care, 181(8), 1047-1061. https://doi.org/10.1080/03004430.2010.509796.

Richards, H. V., Brown, A. F., \& Forde, T. B. (2007). Addressing diversity in schools: Culturally responsive pedagogy. Teaching Exceptional Children, 39(3), 64-68. 
Rivkin, S. G., Hanushek, E.A., \& Kain, J.F. (2005). Teachers, schools, and academic achievement. Econometrica, 73, 417-458. https://doi.org/10.1111/j.14680262.2005.00584.x.

Roegholt, S., Wardekker, W., \& Van Oers, B. (1998). Teachers and pluralistic education. Journal $\quad$ of $\quad$ Curriculum $\quad$ Studies, 30(2), 141. https://doi.org/10.1080/002202798183666.

Sak, R., Tantekin-Erden, F., \& Morrison, G. S. (2016). Child-centred education: Preschool teachers’ beliefs and self-reported practices, Early Child Development and Care, 186(8), 1185-1202. https://doi.org/10.1080/03004430.2015.1081185.

Sak, R., Tantekin-Erden, F., \& Morrison, G. S. (2018). Preschool teachers’ beliefs and practices related to child-centred education in Turkey. Education 3-13, 46(5), 563-577. https://doi.org/10.1080/03004279.2017.1322995.

Soto, J. M. (2018). Effect of vignette-based demonstration on preschool teachers' awareness of intentional teaching. Unpublish Doctorate Thesis. Minnesota: Walden University.

Stronge, J. H. (2018). Qualities of effective teachers. (3rd Edition). ASCD.

Stronge, J. H., Ward, T. J., \& Grant, L. W. (2011). What makes good teachers good? A crosscase analysis of the connection between teacher effectiveness and student achievement. Journal of Teacher Education, 62(4), 339-355. https://doi.org/10.1177/0022487111404241.

Şahin, İ. T. (2013). Preschool teachers" beliefs and practices related to developmentally appropriate classroom management. Doctoral dissertation. Ankara: Middle East Technical University.

Şahin-Sak, İ. T., Tantekin-Erden, F., \& Pollard-Durodola, S. (2018). Turkish preschool teachers' beliefs and practices related to two dimensions of developmentally appropriate classroom management. Education 3-13, 46(1), 102-116. https://doi.org/10.1080/03004279.2016.1194447.

Şen, H. Ş., \& Erişen, Y. (2002). Öğretmen yetiştiren kurumlarda öğretim elemanlarının etkili öğretmenlik özellikleri. Gazi Üniversitesi Gazi Eğitim Fakültesi Dergisi, 22(1), 99-116. TOÖEGD, Türkiye Okul Öncesi Eğitimini Geliştirme Derneği (2017). “İyi Bir Başlangıç İçin Öğretmen Niteliği” Çalıştayı Hizmetteki Öğretmenin Niteliğini Artırma Çalışma Raporu (18.10.2017).

Uşun, S., \& Cömert, D. (2003). Okul öncesi öğretmenlerinin hizmet içi eğitim gereksinimlerinin belirlenmesi. G. Ü. Gazi Eğitim Fakültesi Dergisi, 23(2), 125-138. 
Wood, A. M. (1998). The effects of teacher enthusiasm on student motivation, selective attention, and text memory. Dissertation for the degree of Doctorate of Philosophy. The University of Western Ontario. London, Ontario. Department of Psychology.

Ziv, A. (1988). Teaching and learning with humor: Experiment and replication. The Journal of Experimental Education, 57(1), 4-15. https://doi.org/10.1080/00220973.1988.10806492.

\section{Summary}

A great deal of scientific evidence exists that, in addition to the experiences in the home environment, out-of-home environments are also influential in supporting children’s cognitive, linguistic, social, and emotional development (Fuligni, Brooks-Gunn and Berlin, 2003). For effective applications of the educational process, basic elements such as educational programmes and educational settings, considered to be among the signs of a good-quality preschool education, can only be used at their best by, undoubtedly, the pre-school teacher. As with all different subject matters in teaching, the characteristics that the ideal pre-school teacher needs to have are open to debate. There is consensus, however, that the teachers' knowledge of child development, their beliefs, and their self-esteem are important for high-quality learning settings. Being a pre-school teacher requires a lot of knowledge, skills, and adequacy acquired both during and after formal education. However, parents, colleagues, and children sometimes claim that some teachers have 'a special something' that sets their teaching apart in terms of quality. In such cases, children fondly remember that special teacher all their lives (Bauer, 2008). In light of this, Colker (2008) lists an efficient pre-school teacher's characteristics as follows: (1) passion about children and teaching, (2) perseverance, (3) risk taking, (4) pragmatism, (5) patience, (6) flexibility, (7) respect, (8) creativity, (9) authenticity, (10) love of learning, (11) high energy, and (12) sense of humor.

\section{Statement of Problem}

The main purpose of this study is to examine the preschool teachers' personal characteristics through vignettes. The second aim is to determine the relationship between the effective pre-school teacher characteristics.

\section{Method}

In the first phase of the study, qualitative research model was used and in the second phase relational scanning model from general scanning models was used. Purposive sampling method was used for the selection of the participants. 54 preschool teachers volunteered to take part in the study. The privacy and confidentiality of the participants ' personal and institutional 
information was taken into account. Therefore nickname was created for each participant. For data collection, a semi-structured interview form composed of various vignettes. The vignettes were created in a way that reflected the 12 different characteristics of a teacher proposed by Colker (2008). The vignettes developed by the researchers were evaluated by three specialists in preschool education and tested for intelligibility in a pilot study with five preschool teachers. In the analysis of data, holistic rubric and correlation analysis were used. The responses of the teachers about the vignettes were written in detail and the validity was tried to be given to the answers of the participants through direct quotations.

\section{Findings}

As a result of the research; that the majority of the participants were enthusiastic and authentic; they need to be improved in terms of being creative; pragmatists and love of learning are inadequate. However, there is a significant negative relationship between being enthusiastic with being a pragmatist and being creative with having a high energy score; a significant positive correlation was found between the perseverance and the appreciation of diversity

\section{Discussion and Conclusion}

In this study, the results obtained in the context of the characteristics that teachers are open to improvement are quite remarkable and worth discussing. Therefore, it needs the support of other research findings in the literature. However, research in the literature presents contradictory information.

It should be noted that the negative relationship between teacher enthusiasm and pragmatism, which is one of the findings of the study, is not surprising, considering that one of the main predictors of teacher enthusiasm is intrinsic motivation and that the teacher's pragmatism is related to the small progress in children with valuable vision. Another finding of the study is the positive relationship between resistance levels and respect for diversities until the end of the teachers. It is clear that teachers who respect diversities and appreciate diversities will be teachers who will challenge opportunities when it comes to children's interests. As a result of the research, it was determined that there was a negative relationship between the creativity and the high energy exhibited by the teachers. According to this, it is possible to say that a teacher who does not pay attention to the learning styles of all children in the classroom can exhibit high energy.

According to results obtained from the research, the development of action plans (undergraduate courses, in-service training, mentoring practice etc.) and experimental research on which plans will be effective can be suggested for increasing the adequacy of these features 
YYÜ Ĕ̌̆itim Fakültesi Dergisi (YYU Journal of Education Faculty), 2019; 16(1):561-593, http://efdergi.yyu.edu.tr

ISSN: 1305-020

that preschool teachers need to be improved. In new research, the effects of different qualitative and quantitative research methods and techniques and teacher characteristics can be investigated. However, research can be more comprehensive by increasing the number of samples by using different sample selection methods. 